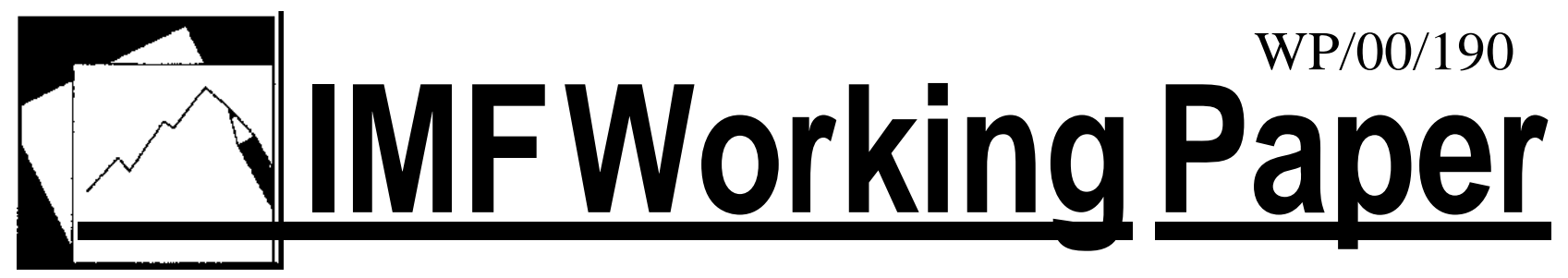

\title{
Emerging Market Spreads: Then Versus Now
}

Paolo Mauro, Nathan Sussman, and Yishay Yafeh 


\title{
IMF Working Paper
}

\author{
Research Department
}

\section{Emerging Market Spreads: Then Versus Now}

\author{
Prepared by Paolo Mauro, Nathan Sussman, and Yishay Yafeh ${ }^{1}$ \\ Authorized for distribution by Eduardo Borensztein
}

November 2000

\begin{abstract}
The views expressed in this Working Paper are those of the author(s) and do not necessarily represent those of the IMF or IMF policy. Working Papers describe research in progress by the author(s) and are published to elicit comments and to further debate.
\end{abstract}

This paper analyzes yield spreads on sovereign debt issued by emerging markets using modern data from the 1990s and newly-collected historical data on debt traded in London during 1870-1913, a previous "golden era" for international capital market integration. Applying several empirical approaches, we show that the co-movement of spreads across emerging markets is higher today than it was in the historical sample. We also show that sharp changes in spreads today tend to be mostly related to global events, whereas countryspecific events played a bigger role in 1870-1913. Although we find some evidence that economic fundamentals, too, co-move more strongly today than at that earlier time, our interpretation of the results is that today's investors pay less attention to country-specific events than their predecessors did in 1870-1913.

JEL Classification Numbers: G15, N20

Keywords: Emerging markets, bond returns, international financial integration

Authors' E-Mail Addresses: pmauro@imf.org, msussman@mscc.huji.ac.il, msyafeh@mscc.huji.ac.il

\footnotetext{
${ }^{1}$ Nathan Sussman and Yishay Yafeh are at the Hebrew University of Jerusalem. Helpful suggestions by Tamim Bayoumi, Eduardo Borensztein, Fabio Canova, Paul Cashin, Gian Maria Milesi-Ferretti, Eswar Prasad, Anthony Richards, Antonio Spilimbergo, and seminar participants at the International Monetary Fund, and research assistance by Grace Juhn and Lilach Weiss are gratefully acknowledged.
} 


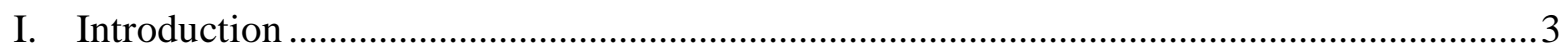

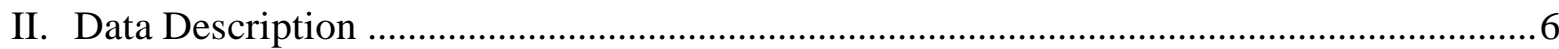

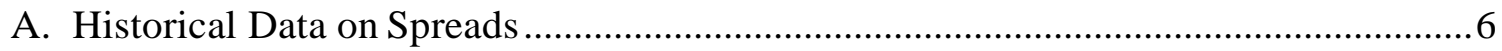

B. Modem Data on Spreads (1992-2000) ..................................................................... 7

C. Data on Exports in Common Currency ................................................................. 11

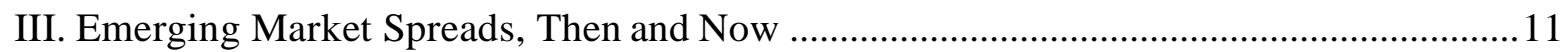

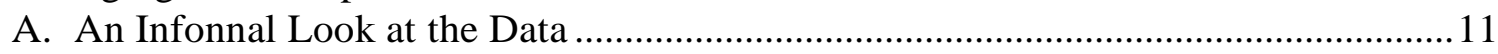

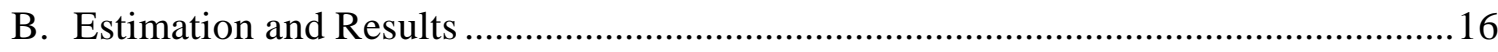

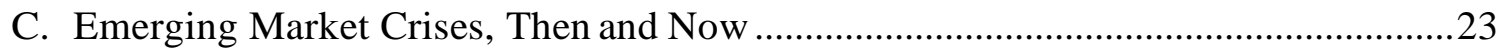

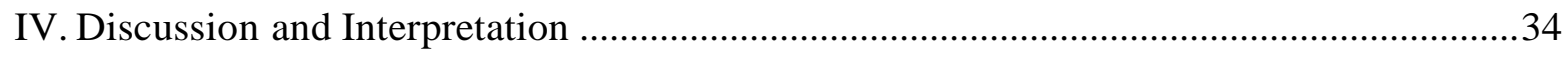

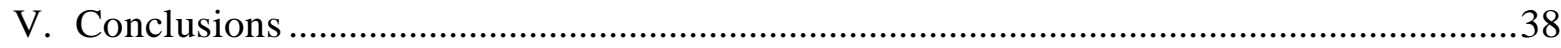

Tables:

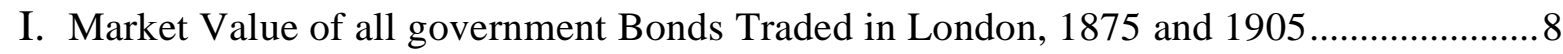

2. Secondary Market Transactions in Debt Instruments, Emerging Markets, 1993-1999......9

3. Secondary Market Transactions in Debt Instruments, Emerging markets, 1993-1999 ... 10

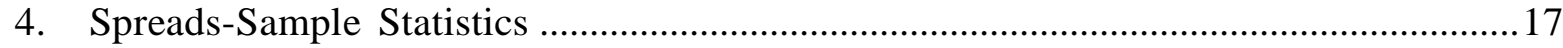

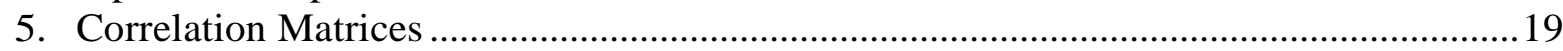

6. Beta Coefficients on Returns in Modem and Historical Samples ....................................22

7. Sharp Changes in Spreads, by Country ......................................................................24

8. Sharp Changes in Spreads, forDifferent Cutoffs ..........................................................25

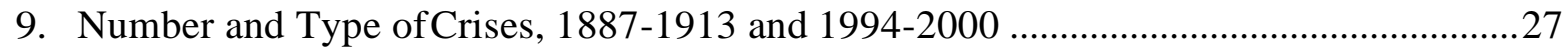

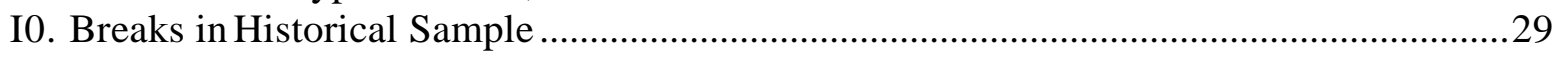

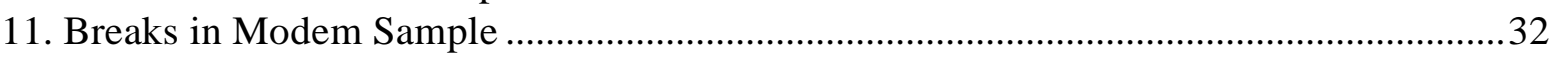

12. The Impact of Events in China on Japanese Spreads, 1870-1914 ..................................33

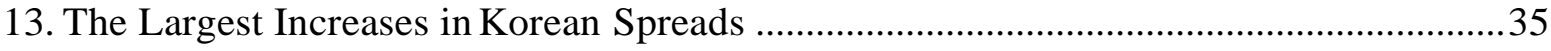

14. The Largest Decreases in Korean Spreads ................................................................. 36

15. Net Proceeds from Bond Issues on the London market, 1870-1913 ............................. 41

16. Share of Total Variation Accounted for by the First Principal Component .................... 43

Figures:

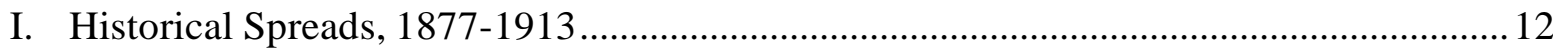

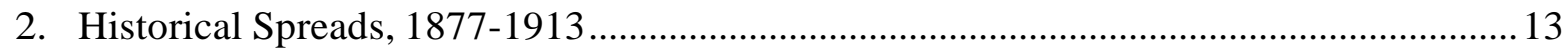

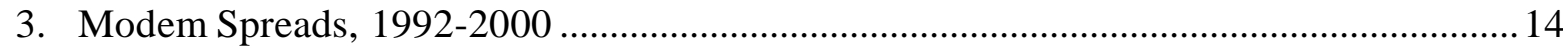

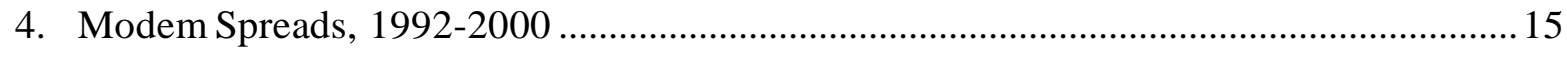

Appendices:

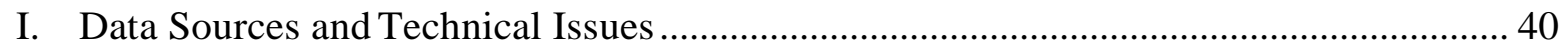

II. Emerging Markets' Bond Issues in London, 1870-1913 ............................................ 41

III. Robustness Tests-Principal Components Analysis.................................................. 42

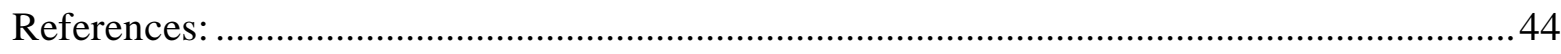




\section{INTRODUCTION}

The frequency and virulence of financial crises that affected emerging markets in the second half of the 1990s have led to calls for reform of the current international financial architecture. Many observers have also wondered whether globalization in international financial markets, perhaps owing to informational and technological advances, has gone too far. The 1990s were characterized by large and volatile private international capital flows toward emerging market countries and, for the first time after several decades, large amounts of sovereign bonds were issued by emerging market countries and actively traded on secondary markets. This paper seeks to shed light on today's international financial environment by comparing it with that of 1870 1913, a previous "golden age" for emerging market bonds and international capital flows toward "emerging markets." Our focus is on sovereign bond yield spreads and on comparing the nature of financial crises and the degree of financial integration in emerging markets, "then" (1870-1913) versus "now" (1992-2000).

There is a growing consensus that global economic integration reached a peak in the late nineteenth and early twentieth century, collapsed with the world wars and the intervening great depression, and gradually increased again after the collapse of the Bretton Woods system to attain levels similar to pre-1914 in the 1990s (Sachs and Warner, 1995). O'Rourke and Williamson (1998) show that capital outflows from Britain to contemporary developing economies were extremely high, and barriers to movement of capital (and labor) were virtually absent. Bordo et al. (1998) describe the period between 1870 and World War I as an era of global finance in which large amounts of foreign securities were actively traded in England. Obstfeld and Taylor (I 998) argue that only in the 1990s did financial integration return to the levels experienced in the era of the classical gold standard.'

Our main contribution is to analyze a newly-collected data set on monthly observations of secondary market yields on sovereign bonds denominated in British pounds and traded in London during 1870-1913, issued by the "emerging markets" of the day, namely Argentina, Brazil, China, Egypt, Japan, Portugal, Queensland, ${ }^{3}$ Russia, Sweden, and Turkey. ${ }^{4}$ We compare the characteristics of those data with a variety of similar data sets on emerging market spreads today. For this purpose, the best modern

\footnotetext{
${ }^{2}$ Obstfeld and Taylor (1998) support this claim by tracking three indicators of international capital integration over the past 130 years: the cross-country mean absolute value of the current account as a share of GDP, the standard deviation of the difference between interest rates on sterling-denominated assets in New York and in London, and the cross-country average absolute real interest differential.

${ }^{3}$ Queensland became an independent British colony in 1859 and one of the states forming the federation of Australia in 190I.

${ }^{4}$ A subset of these data is used to analyze other issues in Sussman and Yafeh (1999 and 2000).
} 
data set on secondary market sovereign bond yield spreads is that on Brady bonds-the largest and most liquid emerging debt market during 1992-2000. ${ }^{5}$ Brady bonds are denominated in U.S. dollars and spreads are computed vis-a-vis yields on U.S. government long-term bonds-just as spreads are computed vis-a-vis British consols for the historical data.

A number of institutional differences in the markets for which data are available "then" and "now" imply that the comparison cannot be perfect. In particular, all countries issuing Brady bonds have previously defaulted on (or restructured) loans from foreign commercial banks, whereas only some countries in the "emerging markets then" group had defaulted prior to 1870 . Conversely, some of the historical emerging market countries defaulted on the bonds we are considering during 1870-1913, whereas no country defaulted on (or restructured) Brady bonds, with the exception of Ecuador in the aftermath of its late 1999 crisis. These differences need to be kept in mind in interpreting the results.

Although it might be argued that the 1990s have been "special" in some sense, perhaps because we all tend to remember more recent crises better, we feel that the 1990s are indeed representative of the "today" that we are interested in, for three reasons. First, it is events in the 1990s that have generated calls for reform of the international financial architecture. Second, the 1990s are the first time since the first world war to see the return oflarge private capital flows toward emerging markets in the form of bonds; under this strict definition of "emerging markets," there were no emerging markets between the first world war and the 1990s. Third, and perhaps most important, crises have not occurred more frequently in the 1990s than in the 1980s or 1970s, as shown by Bordo and Eichengreen (2000) with respect to currency and banking crises. ${ }^{6}$

In comparing 1870-1913 to 1992-2000, we address the following questions. How frequent are crises and sudden improvements in emerging market spreads? To what extent do sharp changes in spreads tend to affect more than one emerging market at a time? How large is the common component in the variation of all emerging market spreads? To what extent do investors benefit from holding a portfolio of bonds issued

${ }^{5}$ The Brady market started with the first restructuring of Mexico's defaulted sovereign loans into Brady bonds in 1990. The stock of outstanding dollar-denominated Brady bonds reached its peak of \$156 billion in March 1997 and has been declining following a series of buybacks and exchanges for uncollateralized bonds and Eurobonds (International Monetary Fund, 1997, p. 75).

${ }^{6}$ Accordingly, in considering crises during the past 120 years, Bordo and Eichengreen (2000) analyze the entire post-Bretton Woods era as one period. They show that the frequency of banking and currency crises of the period since 1973 has been about double that of the Bretton Woods era and the classical gold standard period, and is matched only by that of the 1920s and 1930s. Aziz, Caramazza, and Salgado (2000) show that currency crises were as frequent in the 1970s and 1980s as in the 1990s. Caprio and Klingebiel (1999) report a similar number of banking crises in the 1990s as in the 1980s, and fewer banking crises in the 1970s. 
by several emerging markets rather than by only one emerging market? What kinds of events trigger changes in spreads? Do crises reflect news about macroeconomic developments, political events, or reforms?

To analyze these issues, we adopt a variety of approaches. We consider the number of sharp changes in spreads defined in a number of ways. We then compute the proportion of these changes that affect more than one country at a time. To assess the extent to which the variation in emerging markets' sovereign bond yield spreads is accounted for by a common component, we use principal components analysis. This approach is similar to that adopted by other studies (for example, Nellis, 1982), which use the extent of interest rate variation that is explained by the first principal component to gauge the extent of international financial integration. To analyze the nature of events that cause major changes in spreads, we search the spread series for "structural breaks," and systematically relate the breaks to significant events. We supplement these results by briefly considering two case studies, one relating Japanese spreads to events in China using monthly data for 1870-1913, and one relating Korea's spreads to events in other Asian countries using daily information for 1996--98.

The main conclusions of our empirical analysis are the following:

- For the typical emerging market, financial crises with associated sharp increases in sovereign spreads were common in 1870-1913, though far less common than in the 1990s. Even less common in 1870-1913 were truly "global" crises with increases in sovereign spreads in almost all of the emerging markets, whereas these seem to have been the norm since the early 1990s.

- The proportion of the variance in emerging market spreads accounted for by the first principal component was about $1 / 2$ in the historical sample and about $3 / 4$ in the 1990s.

- The diversification benefits from investing in several emerging markets rather than in only one emerging market are lower today than they were in the past.

- In the historical sample period, most structural breaks in the spread series are related to country-specific (mainly political) events, whereas in the modern sample period most of the breaks are related to global crises.

Increased co-movement of spreads "now" compared with "then" may be due to higher co-movement of economic fundamentals, or different patterns of investor behavior. While providing new evidence that, indeed, economic fundamentals co-vary to a greater extent today than they did in the past, we argue that changes in investor behavior are also an important factor underlying our results.

The remainder of the paper is organized as follows. Section II describes the data sets used for this study. Section III presents the main empirical results on emerging market spreads. Section IV discusses possible interpretations of the main results, and reports additional evidence on fundamentals. Section V concludes. 


\section{DATA DESCRIPTION}

\section{A. Historical Data on Spreads (1870-1913)}

Our data set consists of monthly observations on sovereign bond yields for 18701913. The data were collected by hand from the London Times and The Economist's Investor's Monthly Manual. The data are available daily, but only end-of- the-month observations were collected, owing to resource constraints. All bond coupons were payable in pounds in London. For each emerging market, yields are calculated as the ratio of interest payments to market price' and spreads are computed as the absolute (percentage point) difference between the yields on bonds issued by the emerging market and the yields on British consols. Further detail on the bonds is provided in Appendix I

Our historical sample includes ten contemporary "emerging markets:" Argentina, Brazil, China, Egypt, Japan, Portugal, Queensland, Russia, Sweden, and Turkey. These countries represent some of the major borrowers on the London market and several types of"emerging markets" in terms of their geography, macroeconomic policies, and economic and institutional structure. ${ }^{8}$

Our definition of"emerging markets" is similar to that adopted by Bordo and Eichengreen (2000, henceforth BE), who classify countries as "emerging markets"following modem parlance-using relative per capita incomes and especially on the basis of whether they were net recipients of capital inflows. We apply that definition somewhat more stringently, in the sense that we do not include in our sample some countries, e.g., the United States, that BE classify as emerging markets. By contrast, all countries in our sample that are also considered by BE are classified by BE as emerging markets rather than industrial countries. Countries included in our sample that are not considered by BE (China, Egypt, Russia, and Turkey) are clearly emerging markets using BE's criteria.

The London market for foreign goverrunent bonds during this period was very active and liquid. The total market value of government bonds traded in London was $£ 3$ billion in 1875 and $£ 4$ billion in 1905 , of which $£ 0.5$ billion in 1875 and $£ 1$ billion in 1905 (or 45 percent of Britain's GDP in 1875 and 55 percent of Britain's GDP in

\footnotetext{
${ }^{7}$ This is a reasonable approximation because, for most bonds in our sample, coupon payments take place on a regular basis and the maturity is very long. This procedure is adopted in view of the difficulty of collecting detailed data on each bond's characteristics such as covenants, and options for early calls. Other historical studies adopt a similar procedure-see, for example, the historical data base in http://www.globalfindata.com.

${ }^{8}$ In addition to Queensland (until 1900), only Egypt was a British colony (since 1882) among the countries in our sample.
} 
1905 ) issued by emerging markets in our sample.' Table 1 (which we compiled from The Economist's Investor's Monthly Manual) reports the total market value of bonds traded in London by issuing country. Our sample inclndes the larger emerging markets of the day; it excludes the advanced countries in the industrial core of Europe and the smaller emerging markets. ${ }^{10}$ Complementary evidence from an alternative source (Suzuki, 1994) on bond issuance activity on the London market by the emerging markets in our sample is presented in Appendix II.

\section{B, Modern Data on Spreads (1992-2000)}

The data on emerging market spreads on sovereign bonds denominated in U.S. dollars are drawn from J.P.Morgan and consist of the EMBI (Emerging Markets Bond Index) and EMBI+ bond yield spreads (vis-a-vis yields on U.S. long-term government bonds). EMBI and EMBI+ spreads are the most closely watched indicators of emerging market spreads by market participants, and have been widely used by researchers in previous work.

The EMBI and EMBI+ spreads are available at a daily frequency and-being secondary market spreads-at all times, including times of crisis. By contrast, primary market yields are observed with erratic frequency and are often not available in times of crisis (arguably, the most interesting times), when many countries are just unable to launch new issues.

The EMBI spreads are a weighted average of the spreads on a variety of Brady bonds issued by the country being considered. Yields on those Brady bonds that are collateralized are "stripped" yields, that is, yields after the value of the collateral has been subtracted from the value of the bond. The bonds typically have a long maturity.

Brady bonds were by far the most widespread and actively traded form of emerging market sovereign bonds in the 1990s. Although their relative importance has been declining in recent years, they still accounted for more than half of sovereign debt in the emerging markets surveyed by the Emerging Market Traders Association in 1999 (Table 2). They also accounted for a large portion of the sovereign debt issued by each of the countries considered in our sample (Table 3). The EMBI+ spreads include also a number of non-Brady issues (both sovereign and corporate bonds), but still consist mainly of Brady bonds, reflecting their relative importance in overall market capitalization and trading activity.

In modern times, there was no significant active secondary market for emerging market bonds prior to the introduction of Brady bonds in the early 1990s. Most foreign borrowing by emerging market countries took the form of bank loans. It was only

\footnotetext{
${ }^{9}$ Our own calculations based on The Economist's Investor's Monthly Manual.

${ }^{10}$ In this paper we strive to show that our results are robust to changes in the sample of countries-Appendix III in particular reports a large number of such robustness tests.
} 
Table I. Market Value of all Government Bonds Traded in London, 1875 and 1905.

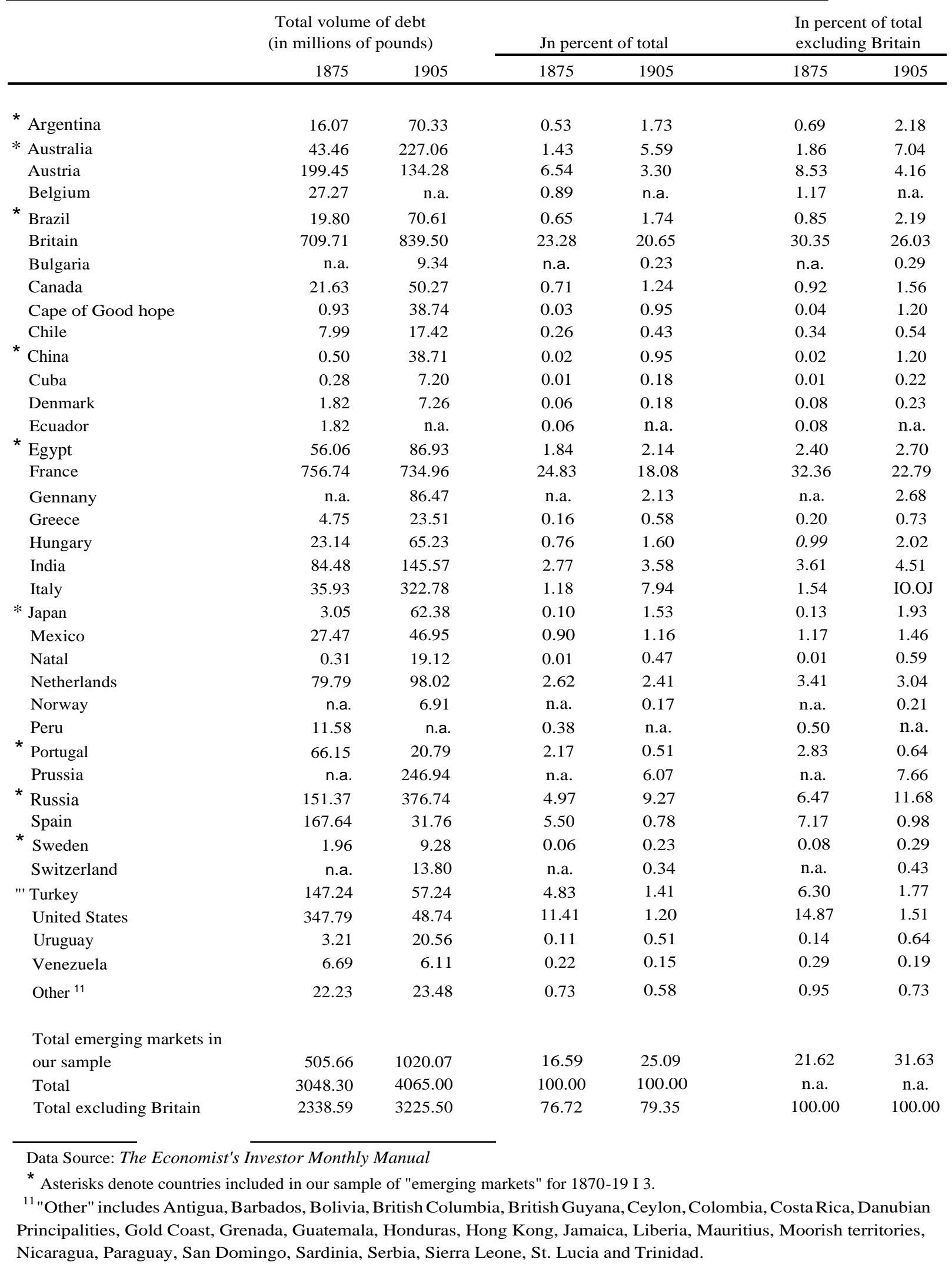


Table 2. Secondary Market Transactions in Debt Instruments, Emerging Markets, 1993-199911

\begin{tabular}{|c|c|c|c|c|c|c|c|}
\hline & 1993 & 1994 & 1995 & 1996 & 1997 & 1998 & 1999 \\
\hline & \multicolumn{7}{|c|}{ (In billions of US dollars) } \\
\hline All instruments & 1979 & 2766 & 2739 & 5297 & 5916 & 4174 & 2185 \\
\hline Brady Bonds & 1021 & 1684 & 1580 & 2690 & 2403 & 1541 & 771 \\
\hline Total Non-Brady Bonds & 177 & 165 & 211 & 568 & 1335 & 1021 & 626 \\
\hline Sovereign Bonds & 88 & 77 & 112 & 327 & 924 & 740 & 431 \\
\hline Corporate and unspecified bonds & 89 & 88 & 99 & 241 & 411 & 281 & 196 \\
\hline Total Local Markets Instruments & 362 & 462 & 593 & 1274 & 1506 & 1176 & 599 \\
\hline Local Currency-denominated & 207 & 371 & 461 & 851 & 977 & 869 & 460 \\
\hline US Dollar-denominated and unspecified & 155 & 92 & 74 & 423 & 529 & 308 & 138 \\
\hline Loans & 274 & 244 & 175 & 249 & 305 & 213 & 69 \\
\hline Options and warrants & 57 & 142 & 179 & 471 & 365 & 223 & 119 \\
\hline Unspecified instruments & n.a. & 12 & n.a. & 45 & 3 & & \\
\hline
\end{tabular}

Source: Emerging Markets Traders Association

${ }^{11}$ All emerging markets surveyed by the Emerging Markets Traders Association 
Table 3. Secondary Market Transactions in Debt Instruments, Emerging Markets, 1993-1999

1993

1994

$\begin{array}{lll}1995 & 1996 \quad 199\end{array}$

1998

1999

\section{All EMTA countries ${ }^{11}$ \\ Total \\ Brady Bonds \\ Non-Brady Sovereign Bonds \\ Other instruments ${ }^{2}$}

Argentina

Total

Brady Bonds

Non-Brady Sovereign Bonds

Other instruments ${ }^{2}$

Brazil

Total

Brady Bonds

Non-Brady Sovereign Bonds

Other instrumcnt $\mathrm{s} 2{ }^{1}$

Bulgaria

Total

Brady Bonds

Non-Brady Sovereign Bonds

Other instruments ${ }^{21}$

Mexico

Total

Brady Bonds

Non-Brady Sovereign Bonds

Other instrumentsv

Nigeria $^{31}$

Total

Philipp ines ${ }^{31}$

Total

Poland

Total

Brady Bonds

Non-Brady Sovereign Bonds

Other instruments ${ }^{21}$

Venezuela

Total

Brady Bonds

Non-Brady Sovereign Bonds

Other instruments 21

$\begin{array}{rrrrrrr}1,979 & 2,766 & 2,739 & 5,297 & 5,916 & 4,174 & 2,185 \\ 1,021 & 1,684 & 1,580 & 2,690 & 2,403 & 1,541 & 771 \\ 88 & 77 & 112 & 327 & 924 & 740 & 431 \\ 870 & 1,005 & 1,047 & 2,280 & 2,590 & 1,893 & 983 \\ & & & & & & \\ 544 & 590 & 610 & 1,292 & 1,236 & 612 & 319 \\ 366 & 361 & 411 & 647 & 533 & 252 & 138 \\ 8 & 14 & 49 & 115 & 304 & 178 & 95 \\ 170 & 216 & 149 & 531 & 399 & 182 & 85\end{array}$

\section{9}

141

14

597

877

583

1,441

1,796

1,269

802

440

1,020

1,102

869

420

104

157

279

394

130

564

320

49

333

$\begin{array}{lllllll}\text { n.a. } & \text { n.a. } & 59 & 106 & 109 & 37 & 20\end{array}$

$\begin{array}{llll}\text { n.a. } & 0 & 57 & 91\end{array}$

n.a. n.a.

n.a.

n.a.

$3 \quad 15$

91

33

15

1

465

$465 \quad 601$

$205 \quad 282$

$46 \quad 25 \quad 36$

214

295

282

946
353
118
476

980

184

145

650

640

313

52

66

195

35

54

33

23

15

4

$$
16
$$

22

14

26

23

24

23

$\begin{array}{lrrrrrr}\text { n.a. } & \text { n.a. } & 96 & 81 & 70 & 95 & 25 \\ \text { n.a. } & \text { n.a. } & 43 & 65 & 36 & 29 & 11 \\ \text { n.a. } & \text { n.a. } & \text { n.a. } & 1 & 2 & 2 & 3 \\ \text { n.a. } & \text { n.a. } & 53 & 15 & 32 & 64 & 11\end{array}$

$\begin{array}{rrrrrrr}288 & 2 & 194 & 397 & 347 & 180 & 95 \\ 262 & \text { n.a. } & 173 & 355 & 248 & 89 & 60 \\ 6 & 2 & 1 & 3 & 46 & 70 & 24 \\ 19 & \text { n.a. } & 20 & 39 & 53 & 21 & 11\end{array}$

Source: Emerging Markets Traders Association

1/ All emerging markets surveyed by the Emerging Markets Traders Association

${ }^{21}$ Including loans, options and warrants, and local market instruments in both domestic and foreign currencies.

${ }_{J I}$ Breakdown by instrument not available. 
following the payments difficulties experienced by a number of emerging market countries (beginning with Mexico) that bank loans were repackaged as Brady bonds and secondary market trading began on a large scale.

As the EMBI yields are based upon Brady bonds, the sample consists of countries that have defaulted, or experienced payments difficulties, on foreign commercial bank loans in the past. Another anomaly observed on Brady bond spreads is a sizable differential between (stripped) yields on Brady bonds and other bonds issued by the same country, controlling for differences in maturity and other factors. Although a number of potential explanations have been put forward for this anomaly, none is fully satisfactory (International Monetary Fund, pp. 75-76).

Despite these drawbacks, the EMBI and EMBI+ spreads are the best available data for our purpose and permit a meaningful comparison between today's emerging markets and those in historical times. To obtain a similar number of countries as that in the historical data set, we analyze the period since November 1994; this gives us daily (or end-of-the-month) EMBI spreads for the following eight emerging markets: Argentina, Brazil, Bulgaria, Mexico, Nigeria, the Philippines, Poland, and Venezuela. To obtain a larger sample (14 countries-Ecuador, Korea, ${ }^{11}$ Morocco, Panama, Peru, and Russia in addition to those listed above) we also analyze daily data on EMBI+ yields since April 30, 1998.

\section{Data on Exports in Common Currency}

The data on exports in common currency used in Section IV are drawn from the following sources. For the historical sample, the data on exports in local currency are drawn from Mitchell (!998) and the data on exchange rates vis-a-vis the British pound are drawn from Schneider et al. (1991). For the modem sample, data on exports in U.S. dollars are drawn from the IMF's International Financial Statistics. Further detail on the data sources is provided in Appendix I.

\section{EMERGING MARKET SPREADS, THEN AND NOW}

\section{A. An Informal Look at the Data}

Simple inspection of the spreads over 1870-1913 and 1992-2000 (Figures I through 4) reveals the following:

- The spreads are substantially higher (in basis points) in modem times than in historical times.

- There is a great deal more common variation across countries in modern times than in historical times. Around the time of the Mexican crisis (December 1994) and the Russian crisis (August 1998) spreads rise in near-unison in most emerging markets. By contrast, in historical times there seem to be many more country-specific developments in the spreads. There are several instances in

\footnotetext{
${ }^{11}$ Korea never restructured, nor defaulted on, its debt.
} 
Figure 1. Historical Spreads, 1877-1913 (in basis points)
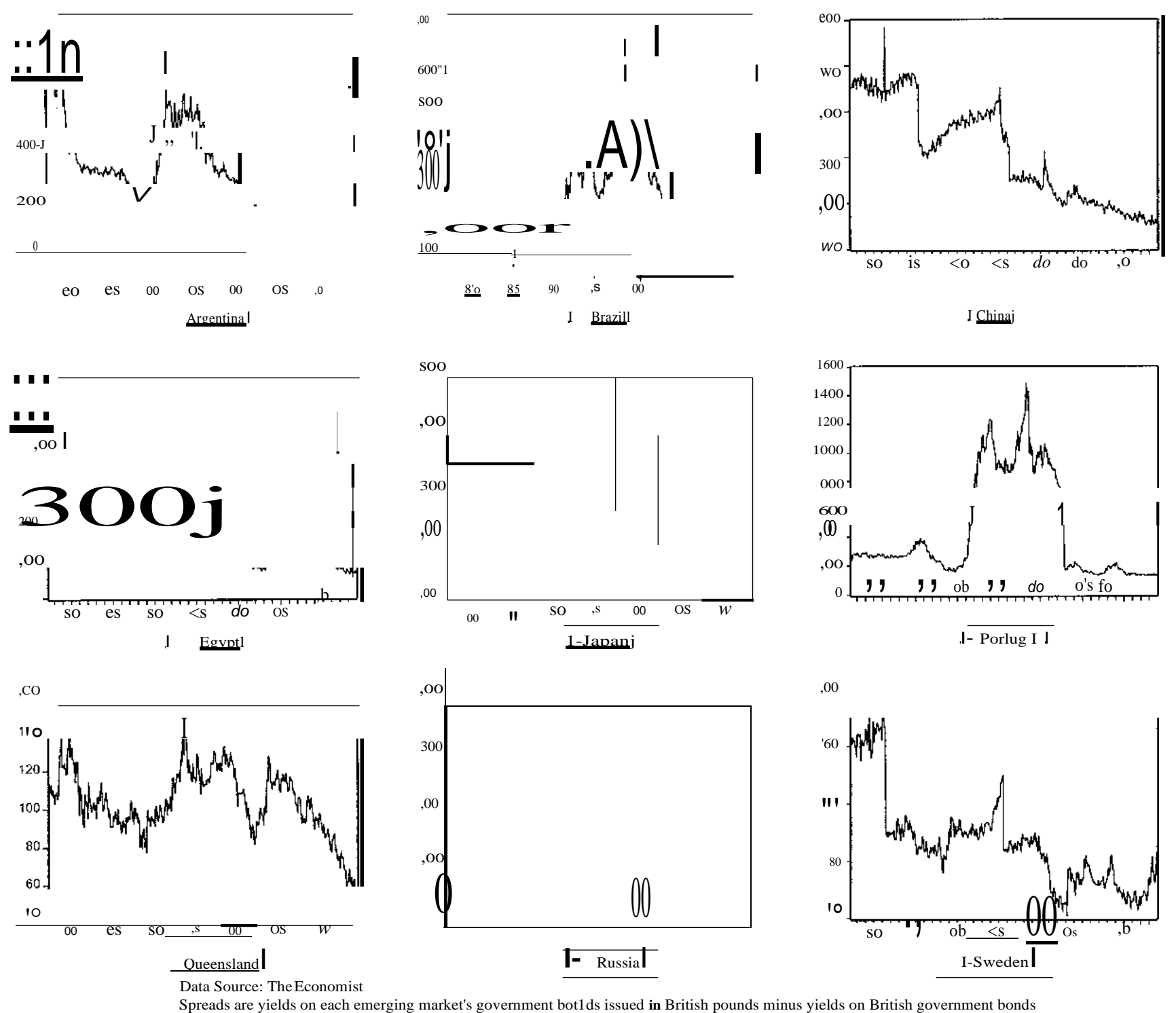

Spreads are yields on each emerging market's government botlds issued in British pounds minus yields on British government bonds 
Figure 2. Historical Spreads (in basis points)

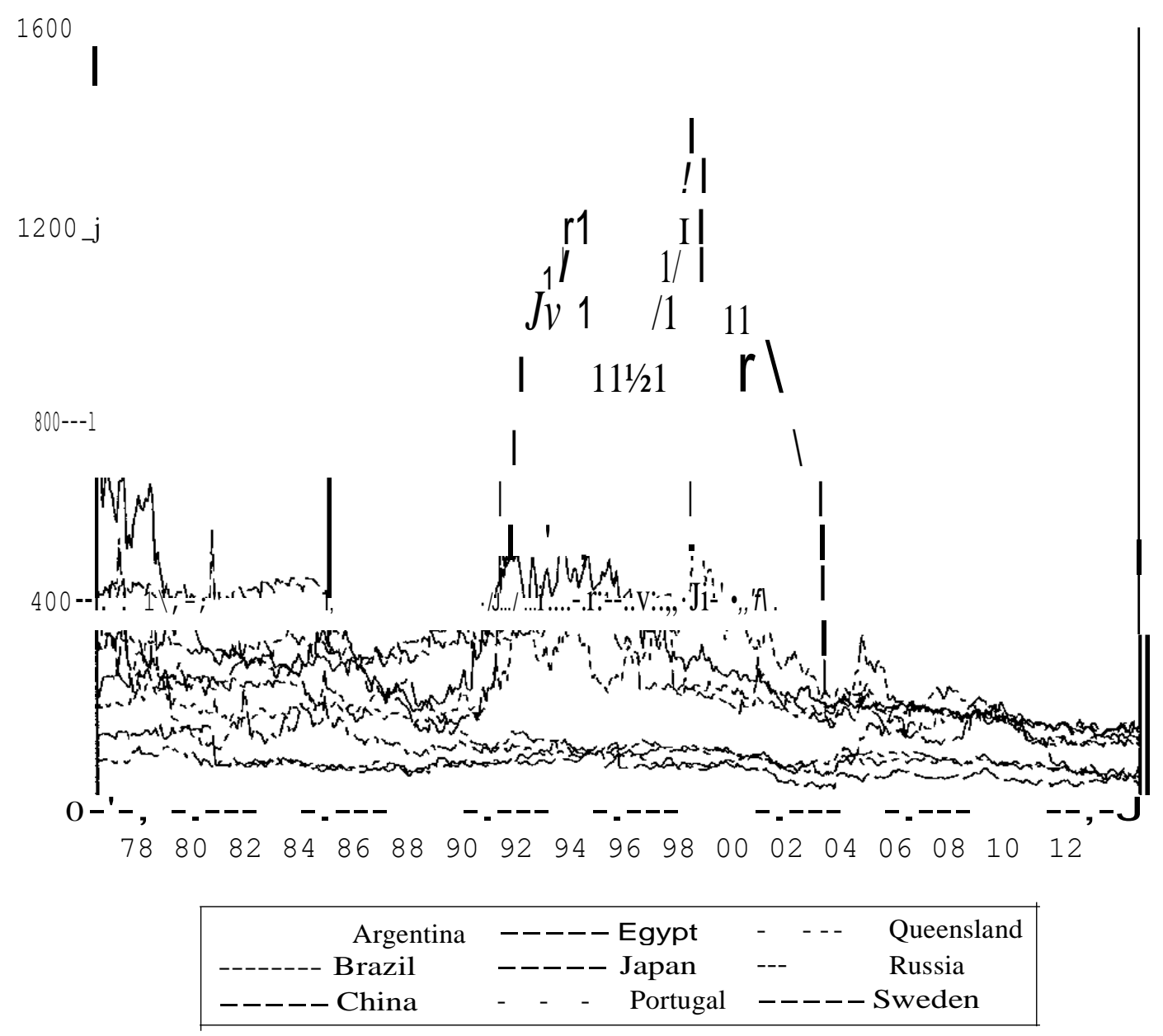

Data Source: The Economist

Spreads are yields on each emerging market's government bonds issued in British pounds minus yields on British government bon ds. 
(sp1;:, 1^ puoq sn snu!w ';;1lruw llmJJ;iw;;, 1pe" Aq sJ11nop sn u! r nssi spuoq -1-u;:,ww;i,.o'.11 uo spr;;:A) spusrnfo IHW3
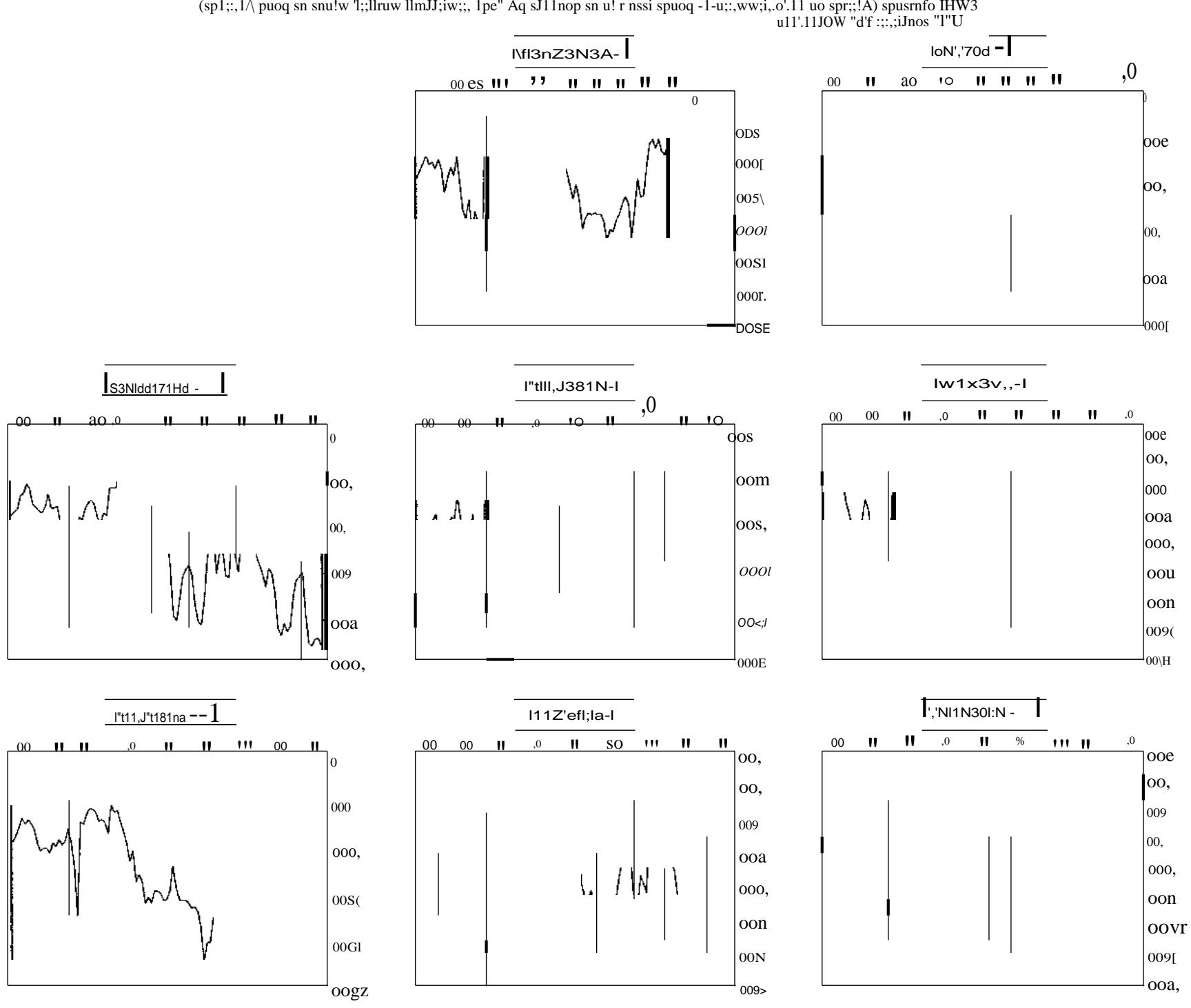

(slU]od s,seq u!) 000Z-Z:661 'sp-eoJdS mapow "£ ;innll]d 
Figure 4. Modern Spreads, 1992-2000 (in basis points)

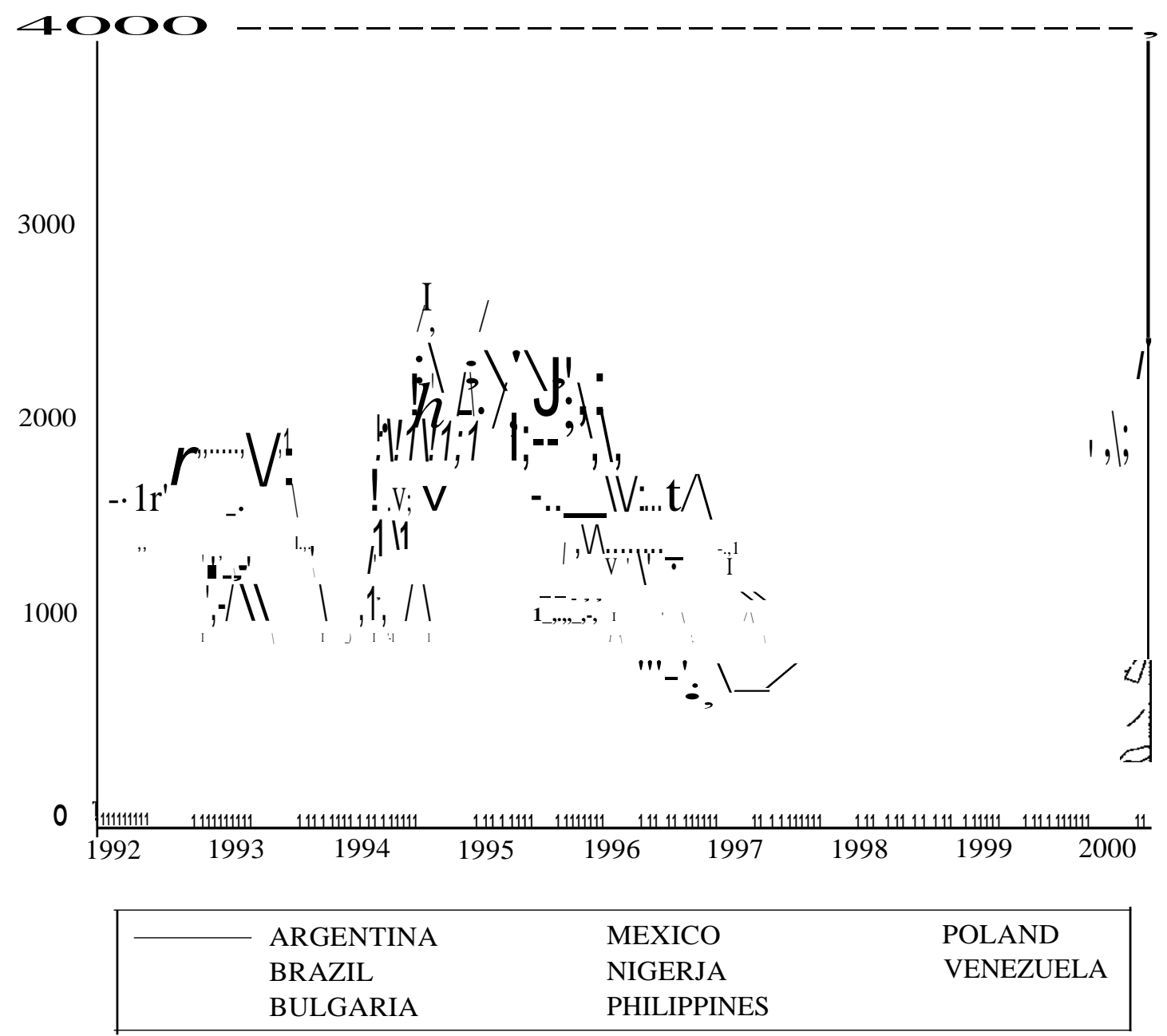

Data Source: J.P. Morgan

EMBI spreads (yields on government bonds issued in US dollars by each emerging market, minus US bond yields) 
which the spread drops in a particular country around the time of an identified country-specific event. For example, the spread on Japanese bonds dropped significantly around the time when the gold standard was introduced (Sussman and Yafeh, 2000).

- The period 1870-1913 saw times of turbulence and sharp changes in spreads, but also tranquil times. By contrast, during 1992-2000 there seems to have been considerable volatility in most countries almost all the time.

The next sections confirm these informal observations using a variety of techniques and testing for robustness of the results.

\section{B. Estimation and Results}

\section{Sample statistics}

In absolute terms, spreads are higher today than in the historical sample. The cross-country mean of the period average spread over the modem sample is around 800 basis points, compared with less than 300 basis points in 1870-1913 (Table 4). This comparison might however be influenced by the fact that interest rates in Britain in the historical sample were much lower than interest rates in the United States in the 1990s (on average, 3.0 percent, compared with 6.8 percent, respectively). The cross-country means of each country's mean spread over the sample period divided by the interest rate in Britain (in historical times) or in the United States (in modem times) amount to 0.815 and 1.24, respectively (omitting Turkey from the historical sample because of data problems, see Appendix I). The difference is statistically significant. Similar results hold using medians instead of means, both over the sample period in one country and cross-sectionally.

The standard deviation of the spreads is typically higher in the modem sample than in the historical sample. However, the cross-sectional average of the coefficient of correlation (the standard deviation divided by the mean) is roughly the same in the modern sample as it is in the historical sample. ${ }^{12}$

As already mentioned in the context of the mean spreads, an important issue is whether the spreads are affected by interest rates in the base country (Britain in the historical sample, the United States in the modem sample). The implications of this

\footnotetext{
${ }^{12}$ A majority of the spread series display considerable skewness (with the long tail in the direction of higher spreads) and, as is often the case with financial data, higher kurtosis than a normal distribution (i.e. fat tails-more frequent extreme events than under a normal distribution). Considering the proportional change in the spreads, in several cases there is again considerable skewness (with the long tail in the direction of larger increases in spreads) and almost all spread series display much higher kurtosis than with a normal distribution. Whether the series are considered in levels or proportional changes, the null hypothesis that they are normally distributed is rejected in virtually all cases.
} 
Table 4. Spreads - Sample Statistics

(In basis points)

Historical Sample (1870:1-1913:12)

\begin{tabular}{|c|c|c|c|c|c|c|c|c|c|c|c|c|c|c|}
\hline & Argentina & Brazil & China & Egypt & Japan & Portugal & Queensland & Russia & Sweden & Turkey & $\begin{array}{c}\text { Cross sectional } \\
\text { mean, emerging } \\
\text { markets }\end{array}$ & $\begin{array}{c}\text { Cross sectional } \\
\text { mean, excluding } \\
\text { Turkey } \\
\end{array}$ & $\begin{array}{c}\text { Cross sectional } \\
\text { median, emerging } \\
\text { markets }\end{array}$ & $\begin{array}{c}\text { Britain } \\
\text { Bond yields } \\
\text { (in percent) }\end{array}$ \\
\hline Mean & 330 & 244 & 310 & 139 & 312 & 438 & 104 & 184 & 104 & 1094 & 326 & 241 & 277 & 2.95 \\
\hline Median & 306 & 217 & 313 & 123 & 336 & 273 & 105 & 177 & 96 & 252 & 220 & 216 & 234 & 2.96 \\
\hline Maximum & 1624 & 653 & 584 & 600 & 623 & 1491 & 149 & 443 & 183 & 8107 & 1446 & 706 & 612 & 3.48 \\
\hline Minimum & 137 & 125 & 151 & 59 & 146 & 125 & 46 & 64 & 41 & -8 & 89 & 99 & 94 & 2.42 \\
\hline Standard Deviation & 164 & 82 & 109 & 77 & 98 & 335 & 17 & 77 & 39 & 1738 & 274 & 111 & 90 & 0.23 \\
\hline Coefficient of variation & 0.50 & 0.34 & 0.35 & 0.55 & 0.32 & 0.76 & 0.16 & 0.42 & 0.38 & 1.59 & 0.54 & 0.42 & 0.40 & 0.08 \\
\hline Skewness & 2.64 & 1.31 & 0.17 & 2.98 & 0.31 & 1.10 & -0.49 & 0.34 & 0.54 & 1.87 & 1.08 & 0.99 & 0.82 & -0.37 \\
\hline Kurtosis & 15.26 & 5.02 & 1.58 & 13.64 & 2.89 & 2.83 & 3.51 & 2.21 & 2.02 & 5.27 & 5.42 & 5.44 & 3.20 & 2.78 \\
\hline Jarque-Bera statistic & 3923 & 214 & 39 & 2737 & 9 & 107 & 24 & 24 & $\%$ & 422 & 755 & 792 & 77 & 13 \\
\hline P-value oftest for normality & 0.00 & 0.00 & 0.00 & 0.00 & 0.01 & 0.00 & 0.00 & 0.00 & 0.00 & 0.00 & 0.00 & 0.00 & 0.00 & 0.00 \\
\hline Observations & 528 & 467 & 440 & 442 & 523 & 528 & 474 & 528 & 528 & 528 & 499 & 495 & 526 & 528 \\
\hline Mean/Britain mean & 1.12 & 0.83 & I.OS & 0.47 & 1.06 & 1.48 & 0.35 & 0.62 & 0.35 & 3.70 & LIO & 0.82 & 0.94 & 1.00 \\
\hline
\end{tabular}

Modern Sample (1992:01-2000:05)

\begin{tabular}{|c|c|c|c|c|c|c|c|c|c|c|c|}
\hline & Argentina & Brazil & Bulgaria & Mexico & Nigeria & Philippines & Poland & Venezuela & $\begin{array}{c}\text { Cross sectional } \\
\text { mean, emerging } \\
\text { markets }\end{array}$ & $\begin{array}{c}\text { Cross sectional } \\
\text { median, emerging } \\
\text { markets }\end{array}$ & $\begin{array}{c}\text { United States } \\
\text { Bond yields } \\
\text { (in percent) }\end{array}$ \\
\hline$\overline{M e a n}$ & 779 & 848 & 1077 & 654 & 1509 & 475 & 309 & 1072 & 840 & 813 & 6.78 \\
\hline Median & 767 & 814 & 926 & 547 & 1567 & 401 & 248 & 960 & 779 & 790 & 6.68 \\
\hline Maximum & 1631 & 1589 & 2154 & 1637 & 2698 & 911 & 861 & 3161 & 1830 & 1634 & 8.42 \\
\hline Minimum & 329 & 362 & 463 & 266 & 545 & 161 & 145 & 264 & 317 & 298 & 4.98 \\
\hline Standard Deviation & 289 & 294 & 430 & 274 & 555 & 221 & 173 & 541 & 347 & 292 & 0.86 \\
\hline Coefficient ofvariation & 0.37 & 0.35 & 0.40 & 0.42 & 0.37 & 0.46 & 0.56 & 0.50 & 0.43 & 0.41 & 0.13 \\
\hline Skewness & 0.68 & 0.42 & 0.45 & 1.22 & 0.00 & 0.48 & 1.56 & 0.84 & 0.71 & 0.58 & 0.02 \\
\hline Kurtosis & 3.14 & 2.44 & 2.10 & 3.95 & 2.04 & 1.99 & 4.51 & 3.68 & 2.98 & 2.79 & 2.15 \\
\hline Jarque-Bera statistic & 7 & 4 & 5 & 29 & 4 & 8 & 34 & 14 & 13 & 7 & 3 \\
\hline P-value oftest for nonnality & 0.03 & 0.12 & 0.10 & 0.00 & 0.15 & 0.02 & 0.00 & 0.00 & 0.05 & 0.03 & 0.18 \\
\hline Observations & 86 & 102 & 67 & 102 & IOI & 102 & 67 & 102 & 91 & 102 & 113 \\
\hline Mean/US mean & 1.15 & 1.25 & 1.59 & 0.97 & 2.23 & 0.70 & 0.46 & 1.58 & 1.24 & 1.20 & 1.00 \\
\hline
\end{tabular}

Data Sources: The Economist and J.P. Morgan website 
issue are pervasive: interest rates in the base country are not only higher but also more volatile in the modem sample than in the historical sample, and it might be argued that higher volatility of interest rates in the base country tends to increase both the volatility and the co-variation of spreads in emerging markets. ${ }^{13}$ This issue is unresolved from both a theoretical and, especially, an empirical standpoint. From the theoretical point of view, Kamin and von Kleist (1999) suggest that an increase in interest rates in the base country would tend to raise the absolute (percentage point) spreads. ${ }^{14}$ Increases in the base country's interest rates may also reduce the emerging countries' creditworthiness, reinforcing the positive effect of base country interest rates on absolute spreads, and mitigating (and possibly overturning) their negative effect on relative spreads.

From the empirical point of view, existing studies (including Kamin and von Kleist, 1999) do not find significant and robust effects of U.S. interest rates on emerging market spreads. Nevertheless, some of the estimates in the following sections control for the effect of interest rates in the base country.

\section{Correlations}

Correlation coefficients for the spreads across pairs of emerging markets are considerably higher in modem times than in historical times. The average correlation coefficient is 0.77 in modem times compared with 0.41 in historical times (Table 5).

All of the correlation coefficients are positive and significant in modern times, whereas there are a number of coefficients that are close to zero (or even negative) in historical times. ${ }^{15}$

${ }^{13}$ Britain's low and stable interest rates in the historical sample period are related to its adherence to the gold standard.

${ }^{14}$ They consider the case of a safe instrument with interest rate $r$ and of a risky instrument that is repaid with probability $\mathrm{p}<1$, with interest rate $i$. In equilibrium, $l+r$ $p(l+i)+(1-\mathrm{p}) 0$, where $r$ is the risk-free rate ofretum in the base country, $i$ is the interest rate paid the risky borrowing country, and $p$ is the probability of no default. They show that the absolute spread, $i-r$, is an increasing function of the base country's interest rate. It is also easy to show that the relative spread, $(i-r) l r$, is decreasing in the base country's interest rate.

${ }^{15}$ The analysis of this paper is not based on cointegration techniques: although there are only few instances in which formal testing (using conventional augmented DickeyFuller tests or Phillips-Perron tests) rejects the null hypothesis of a unit root (probably owing to the limited length of our sample periods), our strong prior is that interest rate spreads are 1(0). Cochrane (1991) points out that interest rates in ancient history were not much different from those observed today, suggesting that the likelihood that interest rates are 1(1) rather than 1(0) is infinitesimal. A fortiori, interest rate spreads should therefore be 1(0) as well. 
Table 5. Correlation Matrices

Historical Sample (1877:5 - 1913:12)

\begin{tabular}{|c|c|c|c|c|c|c|c|c|c|c|c|}
\hline & Argentina & Brazil & China & Egypt & Japan & Portugal & Queensland & Russia & Sweden & Turkey & Britain $\mathrm{fl}$ \\
\hline Argentina & 1.00 & 0.40 & 0.72 & 0.72 & 0.71 & 0.37 & 0.57 & 0.37 & 0.78 & 0.50 & -0.13 \\
\hline Brazil & 0.40 & 1.00 & 0.12 & 0.02 & 0.27 & 0.90 & 0.61 & -0.33 & 0.18 & -0.16 & -0.70 \\
\hline China & 0.72 & 0.12 & 1.00 & 0.65 & 0.80 & om & 0.38 & 0.66 & 0.80 & 0.67 & 0.02 \\
\hline Egypt & 0.72 & 0.02 & 0.65 & 1.00 & 0.50 & -0.09 & 0.29 & 0.70 & 0.74 & 0.76 & 0.17 \\
\hline Japan & 0.71 & 0.27 & 0.80 & 0.50 & 1.00 & 0.26 & 0.51 & 0.40 & 0.65 & 0.37 & -0.31 \\
\hline Portugal & 0.37 & 0.90 & 0.07 & -0.09 & 0.26 & 1.00 & 0.52 & -0.45 & 0.09 & -0.24 & -0.69 \\
\hline Queensland & 0.57 & 0.61 & 0.38 & 0.29 & 0.51 & 0.52 & 1.00 & 0.16 & 0.49 & 0.21 & -0.66 \\
\hline Russia & 0.37 & -0.33 & 0.66 & 0.70 & 0.40 & -0.45 & 0.16 & 1.00 & 0.58 & 0.76 & 0.33 \\
\hline Sweden & 0.78 & 0.18 & 0.80 & 0.74 & 0.65 & 0.09 & 0.49 & 0.58 & 1.00 & 0.71 & 0.01 \\
\hline Turkey & 0.50 & -0.16 & 0.67 & 0.76 & 0.37 & -0.24 & 0.21 & 0.76 & 0.71 & 1.00 & 0.34 \\
\hline Britain JI & -0.13 & -0.70 & 0.22 & 0.17 & -0.31 & -0.69 & -0.66 & 0.33 & 0.01 & 0.34 & 1.00 \\
\hline
\end{tabular}

Average correlation in emerging markets

0.42

Modern Sample (1994:11 - 2000:05)

\begin{tabular}{lcccccccccc} 
& Argentina & Brazil & Bulgaria & Mexico & Nigeria & Philippines & Poland & Venezuela & United States / I \\
\cline { 2 - 9 } Argentina & 1.00 & 0.82 & 0.77 & 0.92 & 0.87 & 0.79 & 0.84 & 0.89 & 0.19 \\
Brazil & 0.82 & 1.00 & 0.44 & 0.83 & 0.79 & 0.66 & 0.60 & 0.87 & -0.25 \\
Bulgaria & 0.77 & 0.44 & 1.00 & 0.71 & 0.58 & 0.62 & 0.76 & 0.64 & 0.59 \\
Mexico & 0.92 & 0.83 & 0.71 & 1.00 & 0.77 & 0.85 & 0.79 & 0.85 & 0.04 \\
Nigeria & 0.87 & 0.79 & 0.58 & 0.77 & 1.00 & 0.79 & 0.79 & 0.88 & 0.04 \\
Philippines & 0.79 & 0.66 & 0.62 & 0.85 & 0.79 & 1.00 & 0.80 & 0.80 & -0.02 \\
Poland & 0.84 & 0.60 & 0.76 & 0.79 & 0.79 & 0.80 & 1.00 & 0.76 & 0.42 \\
Venezuela & 0.89 & 0.87 & 0.64 & 0.85 & 0.88 & 0.80 & 0.76 & 1.00 & -0.03 \\
United States II & 0.19 & -0.25 & 0.59 & 0.04 & 0.04 & -0.02 & 0.42 & -0.03 & 1.00 \\
& & & & & & & & &
\end{tabular}

Average correlation in emerging markets

0.77

Data Sources: The Economist and J.P. Morgan website.

1/ Correlations between British (or US) yields and emerging market spreads. 


\section{Common component}

To gauge the extent of co-movement of these spreads among countries in different sample periods, this section computes the percentage of variation accounted for by the first principal component in the sovereign bond yield spread series for the various emerging market countries considered. The overall result is that the proportion of variance in emerging market spreads accounted for by the first principal component was about $1 / 2$ in 1877-1913, and about $3 / 4$ in the 1990s. Therefore, that proportion was high in historical times, but it is significantly higher in modem times, in both a statistical and an economic sense.

In historical times (1877-1913), and omitting Turkey from the sample, $1^{6}$ the percentage of variation in the nine series accounted for by the first principal component is 52.0 percent-the standard error of that percentage is 2.0 percentage points. ${ }^{17}$

In modem times, the main sample considered is that of the eight emerging markets (Argentina, Brazil, Bulgaria, Mexico, Nigeria, the Philippines, Poland, and Venezuela) for which the EMBI spread data are available since November 1994. Monthly data are used for consistency with the estimates based upon historical data. The percentage of variation accounted for by the first principal component in the sovereign bond yield spread series for these eight series is 80.0 percent. (The standard error of that percentage is 3.1 percentage points. $)^{18}$

Using daily EMBI+ spread series for a larger sample of fourteen countries (Argentina, Brazil, Bulgaria, Ecuador, Korea, Mexico, Morocco, Nigeria, Panama, Peru, the Philippines, Poland, Russia, and Venezuela) since April 30, 1998, the percentage of variation accounted for by the first principal component is 72.2 percent.

Appendix III reports the percentage of variation accounted for by the first principal component when one or two countries at a time are dropped from any of the samples considered above. It shows that this does not alter the result that the percentage

${ }^{16}$ The results are similar if the full crisis episode in Turkey is included in the sample. This requires extending the sample back to 1875, which implies that China and Egypt have to be excluded due to lack of data prior to 1877 . The percentage of variation in the remaining eight series that is accounted for by the first principal component is 45.7 percent-the standard error of that percentage is 1.9 percentage points.

${ }^{17}$ See Appendix I for details on the calculation of the standard errors. The standard errors of the percentage of variation that is accounted for by the first principal component should be interpreted with caution, because they are based upon the assumption that the data are multivariate normally distributed-an assumption that is not fully warranted in this case.

${ }^{18}$ Using daily data for the same sample, the results are similar. The percentage of variation accounted for by the first principal component in the sovereign bond yield spread series for these eight series is 81.3 percent. 
of variation accounted for by the first principal component is higher in modem times than in historical times.

The larger common component in emerging market spreads in modem times than in historical times does not seem to be accounted for by greater variation in interest rates in the base country in modem times than in historical times. To show this, we adopt two approaches. First, we estimate the amount of variation that is accounted for by the first principal component using, for each emerging market-instead of the spreads-the logarithm of the ratio of the interest rate in the emerging market to the interest rates in the base country. (For small spreads, this is approximately equal to the ratio of the spread to the interest rate in the base country.) This method ensures that the estimation ignores all instances in which the same multiplicative change affects both the interest rate in the base country and the interest rate in the emerging market. Using this method, the amount of variation that is accounted for by the first principal component is 57.5 percent (standard error: 2.0 percentage points) in 1877-1913 excluding Turkey; 49.8 percent (standard error: 2.0 percentage points) in 1875-1913 including Turkey; and 81.0 percent (standard error: 3.0 percentage points) in 19942000 .

Second, for each emerging market, we run a univariate regression of the emerging market yield on the interest rate in the base country (Britain in the historical sample and the United States in the modem sample), save the residuals, and then run the principal components estimation on the residuals for all of the emerging market countries. The rationale is to conduct the principal components analysis on that portion of emerging market yields that is orthogonal to the interest rate in the base country. Using this approach, the amount of variation accounted for by the first principal component is 55.8 percent (standard error: 1.9 percentage points) in 1877-1913 excluding Turkey; and 85.0 percent (standard error: 2.5 percentage points) in 19942000 .

\section{Beta coefficients and the benefits of portfolio diversification}

Consistent with the higher common component in emerging market yields today compared with the past, we find that the benefits of holding a portfolio of bonds issued by a variety of emerging market countries rather than by only one country are smaller today than in the past. To show this, for each emerging market country we estimate a univariate regression with the ex-post return (capital gain plus coupon payments) on that country's bonds on the left-hand side and the ex-post return on a marketweighted 19 portfolio of bonds issued by all emerging market countries on the right-hand side. We find that the beta coefficients tend to be considerably closer to one in the modem sample than in the historical sample (Table 6). On average (across countries),

\footnotetext{
"Specifically, we use the EMBI+ "All Emerging Markets" return index for the modem sample and the average of the 1875 and 1905 relative market shares reported in Table I for the historical sample. The results are similar ifwe reweigh the portfolio every five years in the historical sample, and ifwe use daily data instead of monthly data in the modem sample.
} 
Table 6. Beta Coefficients on Returns in Modem and Historical Samples

$R^{\prime} \quad$ Beta $\quad$ Standard error Abs (!-Beta)

Historical Sample (1877 - 1913)

$\begin{array}{lllll}\text { Argentina } & 0.24 & 1.19 & 0.10 & 0.19 \\ \text { Brazil } & 0.20 & 1.04 & 0.10 & 0.04 \\ \text { China } & 0.03 & 0.27 & 0.08 & 0.73 \\ \text { Egypt } & 0.17 & 0.84 & 0.09 & 0.16 \\ \text { Japan } & 0.04 & 0.55 & 0.14 & 0.45 \\ \text { Portugal } & 0.27 & 1.57 & 0.12 & 0.57 \\ \text { Queensland } & 0.16 & 0.37 & 0.04 & 0.63 \\ \text { Russia } & 0.61 & 1.24 & 0.05 & 0.24 \\ \text { Sweden } & 0.02 & 0.14 & 0.05 & 0.86 \\ \text { Average } & 0.19 & 0.80 & 0.09 & 0.43 \\ & & & & \\ \text { Modem Sample (1994-2000) } & & & & 0.15 \\ \text { Argentina } & 0.85 & 0.85 & 0.04 & 0.10 \\ \text { Brazil } & 0.88 & 1.10 & 0.05 & 0.27 \\ \text { Bulgaria } & 0.74 & 1.27 & 0.09 & 0.38 \\ \text { Mexico } & 0.74 & 0.62 & 0.04 & 0.08 \\ \text { Nigeria } & 0.71 & 0.92 & 0.07 & 0.35 \\ \text { Poland } & 0.47 & 0.65 & 0.08 & 0.42 \\ \text { Philippines } & 0.77 & 0.58 & 0.04 & 0.31 \\ \text { Venezuela } & 0.75 & 1.31 & 0.09 & 0.26 \\ \text { Average } & & 0.91 & 0.06 & \end{array}$

Source: The Economist's Investor Monthly Manual and J.P. Morgan website

The beta coefficients are estimated by regressing each country's monthly bond returns on the returns on a market-weighted portfolio of bonds issued by all emerging market countries. 
the absolute difference between one and a country's beta coefficient is 0.43 in the historical sample and 0.26 in the modem sample. (The standard errors for the various countries' beta coefficients range from 0.04 to 0.14 ). The $\mathrm{R}^{2}$ coefficients are far larger in the modem sample than in the historical sample.

\section{Emerging Market Crises, Then and Now}

Financial crises are certainly not a new phenomenon. They occurred frequently and with severe consequences in the late 1800s and early 1900s. "Emerging market" countries often defaulted on their debts: Turkey's default on its foreign debt in the mid1870s was associated with an increase in sovereign spreads of a magnitude not seen since then.' ${ }^{\circ}$ The crash of 1890 in Argentina (and Uruguay, not in our sample) led to the insolvency ofBaring's, the famous London merchant bank. Lindert and Morton (1989) provide a detailed chronology of debt defaults and reschedulings in a very large sample of countries since 1820. As for the ten countries in our sample, they show that several defaults took place--Argentina in 1830 and 1888-1893, Brazil in 1898 and 1914, Egypt in 1876, Russia in 1839, and Turkey in 1876-1881.

Nevertheless, a systematic analysis of sharp changes in sovereign spreads suggests that crises (and sudden improvements in a country's spreads) were less frequent in 1870-1913 than in the 1990s. Specifically, in this section we compute the number of instances in which spreads changed sharply, in 1870-1913 versus 19922000, according to the following definitions:

I) Proportional change in the spread: the spread rises or falls by more than IO percent (20 percent, 30 percent, or 40 percent) of its initial value.

2) Absolute change in the spread: the spread rises or falls by more than 100 basis points (200 basis points, or 300 basis points).

Each of these definitions has advantages and disadvantages. The "proportional change" definition is less sensitive to the fact that the absolute magnitude of spreads (in basis points) is higher during some periods than others; however, it will identify many episodes as "sharp" changes when the spread is close to zero. Conversely, the "absolute change" definition will tend to identify more episodes as "sharp changes" during times of large absolute spreads, but will not do so when the spreads are close to zero.

Using all the data available and a cutoff of 200 basis points, there are 79 sharp changes in the long historical sample and 151 sharp changes in the (much shorter) modem sample. Similarly, using a cutoff of 20 percent, there are 36 sharp changes in the historical sample and I65 in the modem sample (Tables 7 and 8). The difference becomes even more pronounced considering that more than half of the sharp changes in the historical sample took place in Turkey. This result is confirmed when different cutoffs are used. It is also interesting to note that, especially using cutoffs of 30 percent

\footnotetext{
${ }^{20}$ We are unable to compute the exact spreads for Turkey during this crisis and we report an overestimate in the figures and tables, but it is clear that they rose to extremely high values.
} 
Table 7: Sharp Changes in Spreads, by Country

\begin{tabular}{|c|c|c|c|c|c|c|c|c|}
\hline \multirow[b]{2}{*}{ Country } & \multirow[b]{2}{*}{ Sample } & \multirow[b]{2}{*}{$\begin{array}{c}\text { Number of } \\
\text { observations }\end{array}$} & \multicolumn{3}{|c|}{200 basis point changes } & \multicolumn{3}{|c|}{20 percent changes } \\
\hline & & & $\begin{array}{c}\text { Number } \\
\text { of } \\
\text { increases } \\
\end{array}$ & $\begin{array}{c}\text { Number } \\
\text { of } \\
\text { decreases } \\
\end{array}$ & $\begin{array}{c}\text { Share of } \\
\text { observations } \\
\text { (in \%) }\end{array}$ & $\begin{array}{c}\begin{array}{c}\text { Number } \\
\text { of } \\
\text { increases }\end{array} \\
\end{array}$ & $\begin{array}{c}\text { Number } \\
\text { of } \\
\text { decreases }\end{array}$ & $\begin{array}{c}\text { Share of } \\
\text { observations } \\
\text { (in\%) }\end{array}$ \\
\hline \multicolumn{9}{|l|}{ Historical } \\
\hline ARGENTINA & Jan 1870 - Dec 1913 & 527 & 3 & 2 & 0.95 & 3 & 2 & 0.95 \\
\hline BRAZIL & Feb 1875 - Dec 1913 & 466 & 0 & 0 & 0.00 & 1 & 0 & 0.21 \\
\hline CHINA & May 1877 - Dec 1913 & 439 & 0 & 0 & 0.00 & 0 & 0 & 0.00 \\
\hline EGYPT & Mar 1877 -Dec 1913 & 441 & 1 & 0 & 0.23 & 2 & 0 & 0.45 \\
\hline JAPAN & Jun 1870 - Dec 1913 & 522 & 0 & 1 & 0.19 & 0 & 1 & 0.19 \\
\hline PORTUGAL & Jan 1870 - Dec 1913 & 527 & 3 & 3 & 1.14 & 4 & 1 & 0.95 \\
\hline QUEENSLAND & Jul 1874 -Dec 1913 & 473 & 0 & 0 & 0.00 & 0 & 0 & 0.00 \\
\hline RUSSIA & Jan 1870 - Dec 1913 & 527 & 1 & 0 & 0.19 & 2 & 0 & 0.38 \\
\hline SWEDEN & Jan 1870 - Dec 1913 & 527 & 1 & 0 & 0.19 & 1 & 0 & 0.19 \\
\hline TURKEY & Jan 1870 - Dec 1913 & 527 & 34 & 30 & 12.14 & 15 & 4 & 3.61 \\
\hline Total Historical & & 4976 & 43 & 36 & 1.59 & 28 & 8 & 0.72 \\
\hline \multicolumn{9}{|l|}{ Modem } \\
\hline ARGENTINA & Apr 1993 - May 2000 & 85 & 7 & 3 & 11.76 & 11 & 4 & 17.65 \\
\hline BRAZIL & Dec 1991 - May 2000 & 101 & 9 & 4 & 12.87 & 10 & 4 & 13.86 \\
\hline BULGARIA & Nov 1994 - May 2000 & 66 & 5 & 6 & 16.67 & 3 & 3 & 9.09 \\
\hline ECUADOR & Jun 1995 - May 2000 & 59 & 14 & 9 & 38.98 & 8 & 6 & 23.73 \\
\hline MEXICO & Dec 1991 - May 2000 & 101 & 5 & 2 & 6.93 & 10 & 5 & 14.85 \\
\hline NIGERIA & Jan 1992 - May 2000 & 100 & 14 & 17 & 31.00 & 9 & 6 & 15.00 \\
\hline PANAMA & Feb 1997 - May 2000 & 39 & 1 & 0 & 2.56 & 4 & 1 & 12.82 \\
\hline PERU & May 1997 - May 2000 & 36 & 2 & 0 & 5.56 & 5 & 0 & 13.89 \\
\hline PHILIPPINES & Dec 1991 - May 2000 & 101 & 2 & 3 & 4.95 & 11 & 11 & 21.78 \\
\hline POLAND & Nov 1994 - May 2000 & 66 & I & I & 3.03 & 2 & 4 & 9.09 \\
\hline VENEZUELA & Dec 1991 - May 2000 & 101 & 11 & 13 & 23.76 & 14 & 10 & 23.76 \\
\hline KOREA & Apr 1998 - May 2000 & 25 & I & 1 & 8.00 & 5 & 4 & 36.00 \\
\hline MOROCCO & Jan 1998 - May 2000 & 28 & I & 2 & 10.71 & 3 & 4 & 25.00 \\
\hline RUSSIA & Jan 1998 - May 2000 & 28 & 6 & 11 & 60.71 & 4 & 4 & 28.57 \\
\hline Total Modern & & 936 & 79 & 72 & 16.13 & 99 & 66 & 17.63 \\
\hline
\end{tabular}

Source: The Economist's Investor Monthly Manual and J.P. Morgan web site. 
Table 8: Sharp Changes in Spreads, for Different Cutoffs

\begin{tabular}{ccc} 
& $1870-1913$ & $1992-2000$ \\
\cline { 2 - 3 } Cutoff & IO countries & 14 countries \\
4976 observations & 936 observations \\
\hline
\end{tabular}

100 basis points

Sharp increases

\section{8}

65

Sharp changes

Sharp changes/Total

observations (in\%)

200 basis points

Sharp increases

Sharp decreases

Sharp changes

Sharp changes/Total

observations (in\%)

300 basis points

Sharp increases

Sharp decreases

Sharp changes

Sharp changes/Total

observations (in\%)

10 percent

Sharp increases

Sharp decreases

Sharp changes

Sharp changes/Total

observations (in\%)

20 percent

Sharp increases

Sharp decreases

Sharp changes

Sharp changes/Total

observations (in\%)

30 percent

Sharp increases

Sharp decreases

Sharp changes

Sharp changesffotal

observations (in\%)

40 percent

Sharp increases

Sharp decreases

Sharp changes

Sharp changes/Total

observations (in\%)
154

171

325

34.72
43

36

79

1.59

32

26

58

1.17

79

72

151

16.13

76

53

129

2.59

211

233

444

47.44

44

39

83

8.87

Source: The Economist's Investor Monthly Manual and J.P. Morgan web site. 
or above, the number of sharp increases (crises) is much larger than that of sharp decreases, in both the historical and the modem sample. This is consistent with the notion that crises start abruptly but dissipate slowly and gradually, or that instances of panic take place more frequently than sudden improvements in investors' views regarding a given country.

The presence of far more sharp changes in our modem sample than in our historical sample suggests that emerging market crises (and sharp improvements in spreads) have been more common in the 1990s than at the time of the classical gold standard. This result is consistent with the findings of Bordo and Eichengreen (2000) who, using a different definition of crises as currency and banking crises, show that crises were less prevalent in 1880-1913 than in the post-Bretton Woods period (and at least as frequent in the 1970s-1980s as in the 1990s).

In addition, there is evidence that, today compared with the past, there are relatively more instances in which sharp changes (crises or sudden improvements in spreads) take place in several countries rather than in only one country. Specifically, the number of months when sharp changes take place in more than one country as a share of the number of months when sharp changes take place in at least one country is higher in the modem sample than in the historical sample (Table 9). This is the case using any of the cutoff points considered in this paper, although it is most clearly illustrated by focusing on the IO percent cutoff for the historical sample and the 30 percent cutoff for the modem sample. Using these cutoffs, the proportion of months with sharp changes in only one country is roughly the same in the historical and the modem samples-10.2 percent and 10.4 percent, respectively. Nevertheless, in the historical sample the proportion of months with sharp changes in more than one country is I. I percent, compared with 7.5 percent in the modem sample.

\section{Search for breaks}

Before attempting to identify the nature of events that cause sharp changes in spreads, wesearch for"structural breaks" in thespread series, using varioustechniques based on Perron (1989).

\section{An iterative search for breaks}

This method assumes no a priori knowledge of potential break dates. Instead, it is based on using all the available data for repeated estimations of the following equation:

$\log$ (Spread), /Jo+/Ji Jog (Spread),,,+/J,.dlog (Spread),, $+/ J$, Lllog (Spread),,,+J,TREND+/JsEVENTlo,,+/Jr,EVENT, $h_{\circ,,} \quad$ । l)

where EVENTloog is a dummy variable that takes the value zero at all times prior to the proposed break and the value one from the time of the break onwards, and EVENT,h,,, takes the value one at the time of the event, and zero at all other times. If an event has a longterm impact on yields, then the "Jong" dummy variable will be different from zero 
Table 9. Number and Type of Crises, 1887-1913 and 1994-2000.

Number of months with characteristics listed

No sharp changes

Sharp changes in exactly one country

Sharp changes in exactly two countries

Sharp changes in three or more countries

Sharp increases in exactly one country

Sharp increases in exactly two countries

Sharp increases in three or more countries

Sharp decreases in exactly one country

Sharp decreases in exactly two countries

Sharp decreases in three or more countries

Proportion of months with characteristics listed

(As a share of total months in sample period in percent)

Sharp changes in exactly one country

Sharp changes in exactly $t v$.ro countries

Sharp changes in three or more countries

Sharp increases in exactly one country

Sharp increases in exactly two countries

Sharp increases in three or more countries

Sharp decreases in exactly one country

Sharp decreases in exactly two countries

Sharp decreases in three or more countries
Historical Sample (1887:5 - 1913:12)

Modem Sample (1994,I 1- 2000,5)

\begin{tabular}{|c|c|c|c|c|c|c|c|c|c|c|c|c|c|}
\hline \multicolumn{2}{|c|}{$10 \% 20 \%$} & $30 \%$ & $40 \%$ & $\mathrm{I} 00 \mathrm{bp}$ & \multicolumn{2}{|c|}{$200 \mathrm{bps} 300 \mathrm{bps}$} & $10 \%$ & \multicolumn{3}{|c|}{$20 \% 30 \% \quad 40 \%$} & \multicolumn{3}{|c|}{$100 \mathrm{bps} 200 \mathrm{bps} 300 \mathrm{bps}$} \\
\hline 390 & 434 & 438 & 439 & 415 & 435 & 439 & 4 & 26 & 55 & 63 & 11 & 35 & 50 \\
\hline 45 & 5 & 2 & I & 21 & 5 & I & 8 & 26 & 7 & 2 & 16 & 12 & $1 \mathrm{I}$ \\
\hline 4 & 1 & 0 & 0 & 4 & 0 & 0 & 9 & 7 & 2 & 0 & 4 & 10 & 3 \\
\hline 1 & 0 & 0 & 0 & 0 & 0 & 0 & 46 & 8 & 3 & 2 & 36 & 10 & 3 \\
\hline 24 & 3 & 0 & 0 & 7 & 1 & 0 & 15 & 13 & 3 & 1 & 15 & 6 & 4 \\
\hline 2 & 1 & 0 & 0 & 2 & 0 & 0 & 2 & 4 & 1 & 0 & 1 & 6 & \\
\hline 0 & 0 & 0 & 0 & 0 & 0 & 0 & 20 & 4 & 3 & 2 & 15 & 4 & 2 \\
\hline 21 & 2 & 2 & 1 & 14 & 4 & 1 & 9 & 16 & 4 & 1 & 15 & 8 & 7 \\
\hline 2 & 0 & 0 & 0 & 2 & 0 & 0 & 7 & 3 & 1 & 0 & 4 & 5 & 2 \\
\hline 1 & 0 & 0 & 0 & 0 & 0 & 0 & 24 & 3 & 0 & 0 & 18 & 5 & \\
\hline
\end{tabular}

Sources: The Economist's Investor Monthly Manual and J.P.Morgan web site.

The historical sample Includes 9 countries: Argentina, Brazil, China, Egypt, Japan, Portugal, Queensland, Russia, Sweden.

The modern sample includes 8 countries: Argentina Brazil, Bulgaria, Mexico, Nigeria, Philippines, Poland, Venezuela.

The sample periods were chosen to ensure that there are no missing observations. 
(assuming the series is not unit root). A significant "short" dummy implies that an event creates only a short-term "blip." ${ }^{11}$ The method involves repeated estimation of Equation (I) while moving the break date and the corresponding EVENT dummy variables one observation at a time and recording its statistical significance. The sample is then split in two at the point where the statistical significance of the $E V E N T_{10}, \mathrm{~g}$ dummy is highest, and the process is repeated within each half of the sample until no statistically significant break points are detected in any sub-sample.

\section{The "Moving Windows" approach}

An alternative method for searching for breaks at unknown dates in the spread series is based on the construction of a two-year window, which is then shifted by one month at a time. A modified version of Equation (I) is estimated within each "window," and the dates yielding $E V E N T,{ }_{\infty o}$, dummies with the highest statistical significance are recorded. ${ }^{22}$ This method can identify "shorter" breaks more easily than the iterative search based on the whole sample period described in the paragraph above.

\section{The determinants of changes in spreads, "then"versus "now"}

Consistent with our earlier results on the co-movement of spreads "then" versus "now," this section establishes that breaks in the spread series were determined by country-specific events in the historical sample, whereas they are largely associated with global events in the modern sample. Table 10 reports significant breaks in the historical spread series and describe the corresponding events. Evidently, most of the breaks took place at the time of important country-specific events that might be related to the country's ability to repay its external debt. Major political events such as news about the beginning or end of wars and rebellions feature very prominently, as do economic news. For example, a military campaign against indigenous rebels, the end of a civil war, and a domestic revolt were all associated with breaks in Argentina's spread series; similarly, an armed rising and the war against Sudan affected Egypt's spread. Banking crises affected Queensland's spreads. In several cases, changes in domestic monetary policy and regime were also associated with breaks in the spread series. The case of Japan is described in detail in Sussman and Yafeh (2000), who show that the adoption of the Gold Standard (1897) and Japan's victory over Russia (1905) improved Japan's "credit rating" significantly. Similarly, a break in the spread series is observed in Portugal at the time when that country left the Gold Standard. It is important to note that there are no historical instances in which breaks occur simultaneously in a large number of countries. Even the best-documented crisis in the nineteenth century,

\footnotetext{
${ }^{21}$ When the time series is unit root, the EVENTshort dummy variable identifies one-time breaks that have a permanent effect.

${ }^{22}$ Because of the small number of observations within each "window," Equation (I) was estimated using "long" event dummies and "pulse" event dummies separately, but not with both dummy variables together.
} 
Table 10. Breaks in Historical Sample (continued)

\begin{tabular}{|c|c|c|c|c|c|}
\hline Country & Date & Break type & Sign & Significance & Event \\
\hline \multicolumn{6}{|l|}{ Argentina } \\
\hline \multirow[t]{5}{*}{ Major breaks } & $3 / 76$ & event (long) & "+" & 9 & Period of revolution and crisis \\
\hline & $6 / 90$ & event (long) & "+" & 5 & Baring Crisis \\
\hline & $7 / 91$ & event (long) & "+" & 6 & Failure of national bank \\
\hline & $4 / 79$ & event (long) & & 58 & Success against rebellion \\
\hline & $4 / 96$ & event (long) & & 5 & 1 \\
\hline \multirow[t]{7}{*}{ Window breaks } & $10 / 72$ & event (long) & "+" & 4.4 & During Jordan invasions \\
\hline & $11 / 80$ & event (long) & & 4.25 & End of civil war \\
\hline & $7 / 82$ & event (long) & & 4.4 & Period of Monetary reform \\
\hline & $5 / 90$ & event (short) & & 4.5 & pre-Baring \\
\hline & $7 / 93$ & event (long) & "+" & 4.2 & Rebellion \\
\hline & $6 / 97$ & event (long) & & 4,3 & ' \\
\hline & $1 / 08$ & event (long) & "+ & 4.5 & Convertibility crisis \\
\hline \multicolumn{6}{|l|}{ Brazil } \\
\hline \multirow[t]{3}{*}{ Major breaks } & $4 / 98$ & event (long) & "+"; "." & 5,6 & following the crushing ofCanuda rebellion \\
\hline & $10 / 90$ & event (long) & "+" & 3.7 & Going off Gold, Baring crisis \\
\hline & $9 / 95$ & event (long) & "+" & 3,2 & Between revolt of military school and dissolution of congress \\
\hline \multirow[t]{7}{*}{ Window breaks } & $5 n 6$ & event (long) & "+" & 5.5 & ? \\
\hline & $7 \mathrm{n} 8$ & event (long) & "+" & 4 & Conservatives lose power \\
\hline & 11188 & event (long) & $"+"$ & 4.7 & ? Following abolition of slavery \\
\hline & 10195 & event (long) & "+" & 4.4 & Between Revolution and dissolution of congress \\
\hline & $4 / 98$ & event (long) & $"+"$ & 5 & Currency crisis \\
\hline & $5 / 98$ & trend change & & 4.2 & Following the crisis \\
\hline & $4 / 11$ & event (long) & "+ & 4 & Period of bombings \\
\hline \multicolumn{6}{|l|}{ China } \\
\hline \multirow[t]{3}{*}{ Major breaks } & $6 / 85$ & event (long) & & 8.0 & change ofbonds \\
\hline & 5196 & event (long) & & 6.7 & end of war with Japan \\
\hline & $7 / 00$ & event (short) & "+" & 6.0 & Boxers movement \\
\hline \multirow{12}{*}{ Window breaks } & $4 / 79$ & event (long) & & 5.0 & $?$ \\
\hline & $12 / 81$ & event (long) & "+" & 4,5 & $?$ \\
\hline & $2 / 82$ & event (long) & "+ & 4.3 & $?$ \\
\hline & $3 / 83$ & event (long) & "+" & 4.2 & ' \\
\hline & $6 / 85$ & event (long) & & 11.8 & replacement of bonds, end of war in Vietnam \\
\hline & $8 / 91$ & event (long) & "+" & 6.9 & $?$ \\
\hline & $8 / 92$ & event (long) & "+" & 4.9 & $?$ \\
\hline & 4195 & event (long) & - & 4.9 & end of war with Japan \\
\hline & 5196 & event (long) & - & 6.6 & Treaty with Russia; change ofbonds \\
\hline & $6 / 00$ & event (long) & "+" & 5.2 & Boxers movement \\
\hline & 6106 & event (long) & & 4.0 & $?$ \\
\hline & $1 / 09$ & event (long) & "+" & 4.4 & $?$ \\
\hline \multicolumn{6}{|l|}{ Egyp, } \\
\hline \multirow[t]{3}{*}{ Major breaks } & $5 / 79$ & event (long) & & 4.0 & July, Ismail pasha deposed \\
\hline & $9 / 81$ & event (long) & "+" & 3.5 & Armed ri ing \\
\hline & $4 / 85$ & event (short) & "+" & & War against Sudan \\
\hline \multirow[t]{7}{*}{ Window breaks } & 6178 & event (long) & & 5.4 & ? IPO effect? \\
\hline & $6 / 82$ & event (short) & "+" & 4.7 & Britain takes control ofEgypt \\
\hline & $11 / 97$ & event (long) & "+" & 4,0 & , \\
\hline & $11 / 98$ & event (long) & "+" & 4.1 & $?$ \\
\hline & $8 / 08$ & trend change & "" & 4.4 & $?$ \\
\hline & $5 / 10$ & event (long) & "+"' & 4.1 & $?$ \\
\hline & $9 / 12$ & event (short) & "" & 4,0 & $?$ \\
\hline \multicolumn{6}{|l|}{ Japan } \\
\hline \multirow[t]{3}{*}{ Major breaks } & $8 / 97$ & event\{long) & & 9,3 & Going onto gold standard \\
\hline & $3 / 04$ & event (long) & "+" & 4.8 & War with Russia \\
\hline & $6 / 87$ & event (long) & "+" & 3.3 & !! \\
\hline \multirow[t]{5}{*}{ Window breaks } & $4 / 73$ & event (long) & & 6.3 & Agrarian reform \\
\hline & $6 / 86$ & event (long) & & 4,3 & Silver standard \\
\hline & $8 / 97$ & event (long) & & 6,9 & Going onto gold standard \\
\hline & $8 / 98$ & event (long) & & 4.8 & ' \\
\hline & $2 / 05$ & event (long) & & 4.6 & Victory over Russia \\
\hline
\end{tabular}


Table 10. Breaks in Historical Sample (concluded)

\begin{tabular}{|c|c|c|c|c|c|}
\hline Country & Date & Break type & Sign & Significance & Event \\
\hline \multicolumn{6}{|l|}{ Portugal } \\
\hline \multirow[t]{3}{*}{ Major breaks } & $7 / 02$ & event (long) & & 4.3 & Renegotiation of debt \\
\hline & $3 / 91$ & event (long) & "+" & 6.6 & Going off gold standard; bank moratorium \\
\hline & $9 / 07$ & event (long) & "+" & 4.0 & Franco dictatorship; end of monarchy \\
\hline \multirow[t]{6}{*}{ Window breaks } & 1173 & event (long) & "+" & 4.4 & $?$ \\
\hline & $5 / 80$ & event (long) & "+" & 4.0 & $?$ \\
\hline & $5 / 81$ & event (long) & & 4.7 & $?$ \\
\hline & $8 / 98$ & event (long) & & 4.7 & End of hostilities with Germany?, Treaty with Britain negotiated \\
\hline & $9 / 02$ & event (long) & & 15.0 & new bond -following renegotiation of <lebl \\
\hline & $1 / 04$ & event (short) & "+" & 4.5 & \\
\hline \multicolumn{6}{|l|}{ Queensland } \\
\hline \multirow[t]{3}{*}{ Major breaks } & $1 / 91$ & event (long) & "+" & 3.6 & Bank Crisis \\
\hline & $9 / 80$ & event (long) & & 3.0 & $?$ \\
\hline & $4 / 93$ & event (long) & "+" & 35 & Bank Crisis \\
\hline \multirow[t]{3}{*}{ Window breaks } & $7 / 78$ & event (long) & "+" & 4.3 & $?$ \\
\hline & $11 / 86$ & event (long) & "+" & 4.4 & $?$ \\
\hline & $1 / 89$ & event (long) & "+" & 4.6 & $?$ \\
\hline \multicolumn{6}{|l|}{ Russia } \\
\hline \multirow[t]{3}{*}{ Major breaks } & $4 m$ & event (long) & "+" & 7.4 & War with Turkey \\
\hline & $4 / 85$ & & & & bond change \\
\hline & $2 / 03$ & event (long) & & 3.9 & hostilities vs. Japan? \\
\hline \multirow[t]{13}{*}{ Window breaks } & $4 / 78$ & event (long) & & 4.8 & end of war with Turkey \\
\hline & $5 / 79$ & event (long) & & 4.2 & $?$ \\
\hline & $11 / 81$ & event (long) & "+" & 4.4 & following assassination of Alexander II \\
\hline & $3 / 85$ & event (long) & "+" & 5.1 & ? \\
\hline & $7 / 86$ & event (long) & "+" & 5.0 & attempted assassination of Tzar \\
\hline & $1 / 91$ & event (short) & & 4.6 & Trans Siberian railway?, new bond \\
\hline & $10 / 93$ & event (long) & & 6.3 & Treaty with France \\
\hline & $1 / 95$ & event (short) & ," & 5.5 & $!$ \\
\hline & $12 / 96$ & event (short) & & 4.0 & \\
\hline & $4 / 97$ & event (long) & "+" & 4.1 & $?$ \\
\hline & $7 / 97$ & event (long) & & 4.1 & Going onto gold standard \\
\hline & 9105 & event (short) & & 52 & End of war with Japan \\
\hline & $11 / 10$ & event (long) & & 4.0 & $?$ \\
\hline \multicolumn{6}{|l|}{ Sweden } \\
\hline \multirow{9}{*}{$\begin{array}{l}\text { Major breaks } \\
\text { Window breaks }\end{array}$} & $6 / 81$ & event (long) & & 8.4 & ? Change of bonds \\
\hline & $9 / 79$ & event (short) & & 4.2 & $?$ \\
\hline & $7 / 81$ & event (long) & & 21.0 & change ofbonds \\
\hline & $10 / 83$ & event (long) & "+" & 4.3 & $?$ \\
\hline & 4194 & event (long) & "+" & 4.3 & reduction of interest rate on 1880 bond \\
\hline & $8 / 95$ & event (long) & - & 8.0 & change ofbonds \\
\hline & $11 / 99$ & event (long) & & 4.1 & replaced existing bonds with new ones with lower coupon rate \\
\hline & $3 / 01$ & event (long) & & 4.1 & replaced existing bonds with new ones with !ower coupon rate \\
\hline & $8 / 08$ & event (long) & & 4.5 & new bond \\
\hline \multicolumn{6}{|l|}{ Turkey } \\
\hline \multirow[t]{4}{*}{ Major breaks } & $7 / 75$ & event (long) & "+" & 3.5 & Trouble in Bosnia \\
\hline & $5 / 78$ & event (long) & & 4.8 & End of war with Russia, introduction of gold standard \\
\hline & 9195 & event (long) & "+" & 4.4 & War against Greece \\
\hline & $10 / 12$ & event (short) & "+" & 6.0 & war in Balkans \\
\hline \multirow[t]{11}{*}{ Window breaks } & $7 / 71$ & event (long) & & 4.1 & \\
\hline & $! \mathrm{s} / 73$ & event (long) & "+" & 4.8 & moratorium on debt \\
\hline & $8 / 74$ & event (short) & & 4.3 & 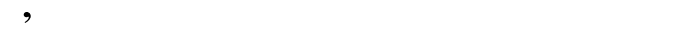 \\
\hline & $5 / 77$ & event (long) & "+" & 5.9 & war with $\mathrm{Ru}$ sia \\
\hline & $5 / 78$ & event (long) & - & 8.0 & End of war with Russia; going onto gold standard \\
\hline & $10 / 80$ & event (long) & - & 4.5 & Civil code, debt administration \\
\hline & $1 / 84$ & event (long) & - & 16.0 & reduction of interest rate on old debt \\
\hline & $9 / 85$ & event (long) & & 6.3 & end of conflict over Egypt \\
\hline & $10 / 95$ & event (long) & "+" & 5.1 & Tensions in Crete leading to war with Greece \\
\hline & $5 / 97$ & event (long) & & 4.2 & Conclusion of war with Greece \\
\hline & $5 / 98$ & event (long) & - & 4.1 & $1 /$ \\
\hline
\end{tabular}

Sources: The Economist Investor's Monthly Manual

The breaks are identified through an iterative procedure as described in the text. 
Earing's Crisis of 1890, did not result in significant breaks in more than two countries, and certainly not in distant countries. ${ }^{23}$

By contrast, in modern times global events had a far more pervasive impact on emerging markets' spreads than any country-specific events. In our sample of eight emerging markets during 1994-98, there is one major break-in August 1998, at the time of the Russian crisis affecting all countries; in addition, the Mexican crisis of late 1994 also had a discernible impact on Mexico and Venezuela; otherwise, there are very few breaks associated with events taking place in the country under consideration (Table 11). The one country-specific break that we find convincing is that associated with the introduction of the currency board in Bulgaria (which formally took place on July I, 1997). And of course, the countries in our 1990s sample did not experience any shortage of major political and economic events: these included coups, assassinations of key political figures, violent uprisings (in some cases by ethnic minorities), the suspension of existing constitutions, the adoption of new constitutions, major changes in the party in power, changes in the domestic currency, and the establishment of common trade areas. $^{24}$

The fact that we typically capture only one major break per country in the spread series in our modern sample is consistent with the finding in the earlier sections that sharp changes in the spreads are relatively frequent in the 1990s. In fact, our systematic search for breaks tends to pick only sustained changes in mean spreads, whereas most sharp changes are reversed after a shorttime.

\section{A historical case study: events in China and Japanese spreads, 1870-1913}

In this section we examine the impact of events in China on Japanese spreads by constructing "windows" around several important events that took place in China, and by using Equation (1) to estimate their impact on Japanese spreads. The results indicate that none of the major political and economic events that took place in China during the period (other than ones in which Japan was directly involved) had much impact on the risk British investors associated with Japanese sovereign debt (Table 12). The Boxers Movement (also known in the West as the Boxer Rebellion), in the suppression of which Japan took part, had only a small and marginally significant impact on Japan's spread; that impact was short-lived, and lasted only for the

${ }^{23}$ See Eichengreen (1997) for a discussion of the crisis and its impact. Sussman and Yafeh (1999) examine the impact of this episode on Japanese yields using a "window" around the crisis peak (November 1890), and find that the Baring Crisis did not have any impact on Japanese spreads. If anything, there was a slight increase in the price of Japanese bonds, suggesting that investors may have shifted some of their money into Japanese bonds, rather than run away and spread the crisis. The effect of the Baring Crisis on Japanese bond prices remains positive albeit statistically insignificant even when dailydata are examined around the peak of the crisis.

${ }^{24} \mathrm{~A}$ full list of such major events that might a priori have been considered capable of having a significant impact on spreads is available from the authors upon request. In this context it is also worth noting that one could make a case that the Mexican crisis and, to a lesser extent, the Russian crisis, were prompted in part by domestic political events. 
Table 1I. Breaks in Modern Sample

Country Date Break type Sign Significance Event

$\begin{array}{lllll}\text { Argentina } & & & & \\ \text { Major breaks } & 8 / 98 & \text { event (long) } & \text { "+" } & 5.5 \\ \text { Window breaks } & 8 / 98 & \text { event (long) } & \text { "+ } & 4.8\end{array}$

\section{Brazil}

$\begin{array}{lllll}\text { Major breaks } & 8 / 98 & \text { event (long) } & \text { "+ } & 4.9 \\ & 3 / 94 & \text { event (long) } & "+ & 3.0 \\ \text { Window breaks } & 8 / 98 & \text { event (long) } & \text { "+11 } & 4.7\end{array}$

\section{Bulgaria}

$\begin{array}{llllll}\text { Major breaks } & 8 / 98 & \text { event (long) } & \text { "+" } & 5.2 & \\ & 4 / 97 & \text { event (long) } & \text { "'" } & 3.6 & \text { currency board forthcoming } \\ \text { Window breaks } & 8 / 98 & \text { event (long) } & \text { "+" } & 6.9 & \end{array}$

\section{Ecuador}

Major breaks $\quad 8 / 98 \quad$ event (long) $\quad$ "+ $\quad 4.8$

Window breaks $\quad 8 / 98$ event (long) $\quad$ "+ $\quad 4.8$

\section{Mexico}

$\begin{array}{llllll}\text { Major breaks } & 8 / 98 & \text { event (long) } & "+" & 4.3 & \\ & 10 / 94 & \text { event (long) } & "+ & 4.0 & \\ \text { Window breaks } & 12 / 94 & \text { event (long) } & "+ & 5.6 & \text { Financial crisis - sharp devaluation } \\ & 8 / 98 & \text { event (long) } & \text { "+ } & 4.3 & \end{array}$

\section{Nigeria}

$\begin{array}{lllll}\text { Major breaks } & 8 / 98 & \text { event (long) } & \text { "+" } & 6.0 \\ & 1 / 94 & \text { event (long) } & \text { "+" } & 3.8 \\ \text { Window breaks } & 8 / 98 & \text { event (short) } & \text { "+ } & 6.0\end{array}$

\section{Philippines}

$\begin{array}{lllll}\text { Major breaks } & 8 / 98 & \text { event (long) } & \text { "+" } & 5.3 \\ \text { Window breaks } & 8 / 98 & \text { event (short) } & \text { "+ } & 6.4\end{array}$

Poland

$\begin{array}{lllll}\text { Major breaks } & 8 / 98 & \text { event (long) } & \text { "+ } & 5.6 \\ \text { Window breaks } & 8 / 98 & \text { event (short) } & ++ & 5.3\end{array}$

Venezuela

$\begin{array}{llllll}\text { Major breaks } & 8 / 98 & \text { event (long) } & \text { "+" } & 7.5 & \\ & 1 / 94 & \text { event (long) } & \text { n+" } & 4.6 & \\ \text { Window breaks } & 3 / 94 & \text { event (long) } & \text { "+!1 } & 4.4 & \text { Financial crisis } \\ & 8 / 98 & \text { event (long) } & \text { "+" } & 4.3 & \end{array}$

Source: J.P. Morgan

The breaks are identified through an iterative procedure as described in the text. 
Table 12. The Impact of Events in China on Japanese Spreads, 1870-1914

\begin{tabular}{|c|c|c|c|}
\hline Date & Event & $\begin{array}{l}\text { Long-term } \\
\text { break? }\end{array}$ & $\begin{array}{l}\text { Short-term } \\
\text { "bli.2_"? }\end{array}$ \\
\hline December 1883 & $\begin{array}{l}\text { Outbreak of the Chinese-French War } \\
\text { over Vietnam (Annam) }\end{array}$ & None & None \\
\hline June 1896 & Chinese-Russian military alliance & None & None \\
\hline June 1900 & Beginning of the Boxers Movement & None & +0.05 \\
\hline May 1907 & $\begin{array}{l}\text { Instability and revolts in several regions } \\
\text { of China }\end{array}$ & None & None \\
\hline September 1911 & The Chinese Revolution & None & None \\
\hline
\end{tabular}

Data Source: The Economist's Investor Monthly Manual, monthly data.

Note: Any long-term breaks and short-term blips are obtained from a 2-year window approach around major events as explained in the text. 
duration of the movement (i.e., it was a "blip"). Similarly the Japan-China war, which affected Japan directly, only caused a short-term blip.

A modern case study: Korean spreads, 1996-1999

Next, we examine daily movements in spreads on bonds issued by one emerging market, Korea. Considering the "worst twenty days" in which the spread on Korean sovereign bonds increased by the highest percentage, and "the best twenty days," a majority of the largest fluctuations in Korea's spread were associated with events that took place outside Korea, and often in countries whose fundamentals are not clearly related to Korea's (Tables 13 and 14). For example, rumors about Indonesia's president Suharto's health influenced Korean spreads, in sharp contrast with our historical case study.

\section{DISCUSSION AND INTERPRETATION}

The picture that seems to emerge is one in which, today compared with the past, major breaks in the spread series are less related to events taking place in the country under consideration, and the co-movement of spreads across countries is higher. There are a number of possible explanations for this, ranging from differences in investor behavior to increased correlation of economic fundamentals among emerging markets.

We find evidence that the correlation among emerging markets' economic fundamentals is higher today than in the past. The closest proxy for economic fundamentals that we have been able to obtain for 1870-1913 is exports in pounds sterling-a variable clearly related to an emerging market's ability to repay its external debt. ${ }^{25}$ We use the annual rate of change of exports in common currency to proxy for news about each country's fundamental ability to repay its external debt. To obtain a comparable measure of the correlation of economic fundamentals at the annual frequency in modem times, we use exports in U.S. dollars during 1966--98 for our sample of countries.

For 1871-1913, the first principal component accounts for 29 percent (standard error: 4.8 percentage points) of the variation in the growth rate of exports of the eight countries for which we have good data. For 1966--1998, the first principal component accounts for a significantly higher proportion-54 percent (standard error: 6.7 percentage points $\}$-ofthe variation in the growth rate of exports of the seven countries for which we have good data. The average correlation coefficient in the growth rate of exports in common currency across pairs of countries is 0.15 in 1871-1913 and, at

\footnotetext{
${ }^{25}$ Other variables, such as gross domestic product or industrial production, are not suitable for this exercise. Gross domestic product (or other measures of overall output) are available for a very limited number of countries; industrial production is also available only for a smaller sample and is not representative of economic activity in emerging markets, which consisted largely of agriculture and natural resource extraction.
} 
Table 13. The Largest Increases in Korean Spreads

(The Worst Twenty Days)

\begin{tabular}{|c|c|c|c|c|}
\hline Rank & Date & Event & $\begin{array}{c}\text { Increase in } \\
\text { spreads } \\
\text { (in percent }\end{array}$ & $\begin{array}{l}\text { Effect on } \\
\text { other } \\
\text { countries? }\end{array}$ \\
\hline$(!)$ & $27 / 10 / 97$ & Bad economic news from Hong Kong* & 27.53 & Th, Indon \\
\hline (2) & $30 / 10 / 97$ & Bad economic news from Hong Kong & 25.59 & Th, Indon \\
\hline (3) & 02/06/98 & Labor disputes?* & 24.90 & No \\
\hline (4) & $23 / 10 / 97$ & Bad economic news from Hong Kong & 24.37 & Th, Indon \\
\hline$(5)$ & $10 / 12 / 97$ & $\begin{array}{l}\text { Government suspends five cash strapped } \\
\text { compames }\end{array}$ & 23.48 & Indon \\
\hline (6) & $23 / 12 / 97$ & $\begin{array}{l}\text { Credit agencies downgrade Korean } \\
\text { sovereign debt }\end{array}$ & 22.95 & No \\
\hline (7) & $21 / 08 / 98$ & Russian default* & 21.59 & Mal, Indon \\
\hline$(8)$ & $19 / 03 / 97$ & $?$ & 21.26 & Indon \\
\hline (9) & $22 / 12 / 97$ & $\begin{array}{l}\text { Moody's lowers ranking of Korean } \\
\text { sovereign debt to junk }\end{array}$ & 20.18 & Th, Indon \\
\hline$(10)$ & $11 / 12 / 97$ & $\begin{array}{l}\text { Moody's lowers ranking of Korean } \\
\text { sovereign debt }\end{array}$ & 19.79 & Th, Indon \\
\hline$(11)$ & $19 / 12 / 97$ & $\begin{array}{l}\text { Korea Investors Service downgrades } \\
\text { chaebol affiliates }\end{array}$ & 17.97 & No \\
\hline$(12)$ & $16 / 06 / 98$ & 55 firms about to fail & 17.64 & No \\
\hline$(13)$ & 02/09/97 & Trouble selling $\mathrm{Kia}^{*}$ & 14.78 & No \\
\hline$(14)$ & I 0/09/98 & Bad economic news from Brazil & 14.29 & Lat Arn \\
\hline$(15)$ & $09 / 12 / 97$ & $\begin{array}{l}\text { Stocks and won plunge - "investor } \\
\text { worries" }\end{array}$ & 13.77 & No \\
\hline$(16)$ & $25 / 08 / 97$ & S\&P may cut Thailand's rating & 13.70 & No \\
\hline$(17)$ & $25 / 11 / 97$ & $\begin{array}{l}\text { Non-performing loans bigger than } \\
\text { expected }\end{array}$ & 13.19 & No \\
\hline$(18)$ & $27 / 08 / 98$ & Russian default & 13.16 & Th,LatAm \\
\hline$(19)$ & $13 / 01 / 99$ & Bad day in the stock market & 13.12 & $\begin{array}{l}\text { Lat Am, Th, } \\
\text { Indon, Mal }\end{array}$ \\
\hline$(20)$ & $12 / 12 / 97$ & Suharto's health problems & 12.73 & Th,Indon \\
\hline
\end{tabular}

Data Source: Deutsche Bank.

Th, Indon, Mal, and Lat Am denote instances in which a large change (by more than 10 percent) is observed also in the spread on Thai, Indonesian, Malaysian, and both Argentian and Brazilian bonds, respectively. Stars denote events that are found significant in an iterative procedure, as explained in the text. A question mark denotes dates when no major events are reported. 
Table 14. The Largest Decreases in Korean Spreads

(The Best Twenty Days)

\begin{tabular}{|c|c|c|c|c|}
\hline Rank & Date & Event & $\begin{array}{l}\text { Decrease in } \\
\text { premium } \\
\text { (in } 2 \text { crcent) }\end{array}$ & $\begin{array}{c}\text { Effect on } \\
\text { other } \\
\text { countries? }\end{array}$ \\
\hline (1) & $24 / 12 / 97$ & Overshooting the day before?* & -30.09 & $\mathrm{Th}$ \\
\hline (2) & $21 / 11 / 97$ & $\begin{array}{l}\text { Government to tum to the IMF for } \\
\text { assistance }\end{array}$ & -24.17 & No \\
\hline (3) & $21 / 12 / 98$ & Talk of debt upgrading & -24.09 & No \\
\hline (4) & $10 / 10 / 96$ & Korea joins OECD & -20.99 & No \\
\hline$(5)$ & $19 / 01 / 99$ & Fitch upgrades Korean sovereign debt & -20.40 & No \\
\hline (6) & $18 / 02 / 98$ & $\begin{array}{l}\text { Conglomerates reach accord with foreign } \\
\text { banks* }\end{array}$ & -19.10 & No \\
\hline (7) & $04 / 11 / 97$ & Thai (and Korean) stocks rally & -18.40 & $\mathrm{Th}$ \\
\hline (8) & $16 / 12 / 97$ & $\begin{array}{l}\text { All three presidential candidates will abide } \\
\text { by IMF deal }\end{array}$ & -18.35 & Th, Indon \\
\hline (9) & 04/01/99 & S\&P upgrades Korean sovereign debt & -17.92 & $\mathrm{Th}$ \\
\hline$(10)$ & 29/07/98 & $\begin{array}{l}\text { Agreement with the IMF on revised } \\
\text { economic goals }\end{array}$ & -17.52 & No \\
\hline$(11)$ & $26 / 12 / 97$ & Financial markets fully open to foreigners & -12.46 & No \\
\hline$(12)$ & 09/09/97 & KDB issues $\mathrm{rn} \$ 750$ bonds in US & -12.31 & No \\
\hline$(13)$ & $15 / 01 / 99$ & $?$ & -11.45 & Lat Arn \\
\hline$(14)$ & $23 / 01 / 98$ & $?$ & -11.14 & No \\
\hline$(15)$ & $16 / 02 / 99$ & $\begin{array}{l}\text { Successful negotiations with foreign } \\
\text { creditors }\end{array}$ & -10.94 & No \\
\hline$(16)$ & $13 / 08 / 98$ & $?$ & -10.66 & Argentina \\
\hline$(17)$ & $13 / 01 / 98$ & $\begin{array}{l}\text { Government takes steps to ease cash } \\
\text { crunch; }\end{array}$ & -10.05 & No \\
\hline$(18)$ & $18 / 12 / 97$ & $\begin{array}{l}\text { Reforms and approval of } 2 \text { nd part of IMF } \\
\text { loan }\end{array}$ & -9.77 & No \\
\hline$(19)$ & $25 / 01 / 99$ & $?$ & -9.74 & No \\
\hline$\underline{(20)}$ & $15 / 09 / 98$ & Government to acquire 2 ailing banks & -9.72 & Lat Arn \\
\hline
\end{tabular}

Data Source: Deutsche Bank.

Th, Indon, Mal, and Lat Arn denote instances in which a large change (by more than 10 percent) is observed also in the spread on Thai, Indonesian, Malaysian, and both Argentian and Brazilian bonds, respectively. Stars denote events that are found significant in an iterative procedure, as explained in the text. A question mark denotes dates when no major events are reported. 
0.45 , is much higher in 1966- $1998 .{ }^{26}$ We view this finding as evidence that higher comovement of fundamentals may be one of the factors underlying today's greater comovement of spreads than observed in the past.

The higher co-movement of export growth today is not inconsistent with the high degree of worldwide integration and trade openness of the emerging markets in 1870-1913 documented by previous studies (e.g., O'Rourke and Williamson, 1999). Although the degree of trade openness and integration today is broadly similar to that observed in 1870-1913, the underlying shocks affecting the various emerging markets appear to be more closely correlated now than they were in the past, perhaps owing to greater similarity of industrial structures in today's emerging markets. ${ }^{27}$

However, trade relations are unlikely to be the reason why events in Indonesia today affect Korean spreads, whereas events in nineteenth century China did not influence Japanese spreads. Indeed, trade between Japan and China in the nineteenth century was far more important than trade between Korea and Indonesia is today. ${ }^{28}$

Our results, notably those on the nature of events associated with breaks in the spread series and the evidence from the case studies, therefore raise the possibility that investors today behave differently than investors in the past. We are unable to provide a full explanation for this possible change in behavior, and indeed this is beyond the scope of our paper. Nevertheless, we can confidently rule out one type of explanation: the reason is certainly not lack of information on the part of investors in the nineteenth century. For example, events in China failed to affect Japanese spreads even though investors located in London were well informed about them. Both the London Times and the Economist reported on events in Asia regularly and in detail (see Sussman and Yafeh, 1999, for a list of such news articles): not only did they report on events in China, but also they explicitly emphasized the potential costs for Japan of events in China, whether through commercial links or direct military involvement. For instance, the Economist expressed concern about the implications on Japan's economy of the 1911 Chinese Revolution, and of potential Japanese military intervention in China (December 23, 1911). On the whole, it seems that investors had all necessary information re§arding events in one emerging market that might have consequences for other markets. ${ }^{9}$ Moreover, we are skeptical about potential explanations relying on

${ }^{26}$ Dropping one or two countries at a time, whether in the historical sample or in the modern sample, does not affect the results much. These robustness tests are available from the authors upon request.

${ }^{27}$ In the past, each emerging market tended to specialize in a different commodity. For example, see Estevadeordal's (1997) analysis of the commodity composition of international trade for a number of countries in 1913.

${ }^{28}$ Japan's trade with China as a share of Japan's GNP around 1900 was higher than Korea's trade with Indonesia is today as a share of Korea's GDP. (See the Historical Statistics ofJapan, published by the Japan Statistical Association, and the International Monetary Fund's Direction of Trade Statistics.)

${ }^{29}$ Indeed, some investors devoted a phenomenal amount of highly qualified human resources to obtaining and analyzing information on the economic fundamentals of the various emerging market countries of the day. See Flandreau's (1998) fascinating 
differences in the speed with which information from emerging market countries reached investors in the advanced countries. International telegraph links to the emerging market countries in our sample were introduced in the 1870s, and most of our estimations rely on end-of-the-month data.

Our own interpretation (going beyond merely documenting facts as we have done in the previous sections) of why investors today seem to pay less attention to events taking place in the country under consideration than their predecessors did in the past is that while individual investors played the key role in the past (Suzuki, 1994), the bulk of investment in emerging market bonds is now undertaken through investment funds. From the point of view of individuals, investing in foreign countries through funds may reduce monitoring and transaction costs. Yet when a crisis emerges, these funds tend to liquidate their holdings of securities in several emerging markets so as to maintain a given risk and liquidity profile.

Regarding the issue of why the mean and volatility of the spreads in historical times are lower than today's, we conjecture that two factors could be at play. First, all of the emerging market countries in the modern sample had defaulted prior to the period considered whereas not all those in the historical sample had. As a result, emerging markets today might be viewed by investors as a relatively higher-risk group than our emerging markets in the past were.Jo Second, and more important, several countries in our sample adhered to the gold standard and conducted policies consistent with it for at least part of the historical period we analyze. This may have reduced their spreads-a view corroborated by our findiug that several structural breaks in the spread series (with the expected signs) take place around the time when countries go on or off the gold standard, and by Borda and Rockoffs (1996) result (obtained using a different sample relying on annual data) that countries' commitment to the gold standard significantly lowered their interest rates.

\section{CONCLUSIONS}

In this study, we use a newly-collected data set on sovereign bond yields in emerging markets in 1870-1913, a golden era for international capital flows, together with the most widely used data on sovereign bond yields in emerging markets in 19922000. We establish a number of stylized facts regarding the spreads on sovereign bonds issued by emerging markets. Today compared with the past, sharp changes in spreads are more frequent; the proportion of sharp changes in spreads affecting more than one country is higher; co-movement of spreads among emerging markets is greater; the benefits to investors of portfolio diversification among emerging markets are smaller;

account of such applied research activities by one important investor in emerging markets in 1870-1914, the Credit Lyonnais.

Jo A complementary point of view could be that the modern sample period was immediately preceded by the debt crisis of the 1980s, with its related difficulties in working out a solution; by contrast, during the historical sample period, solutions to default crises may have been easier to work out because the creditors were organized in the Corporation of Foreign Bondholders (see Fishlow, 1985, pg. 398). 
and the relationship between country-specific events and breaks in the spread series is weaker.

We argue that these results may be accounted for by two factors: first, comovement of fundamentals seems to be higher today than in the past; second, today's investors seem to place less emphasis on country-specific events than their predecessors did in 1870-1913. 


\section{DATA SOURCES AND TECHNICAL ISSUES}

The data on emerging market bond yields in historical times refer to the following bonds. For Argentina we use a 6 percent public works bond until 1884; thereafter we use another 6 percent bond issues in 1884 with maturity in 1922 . The Brazilian series consists of 5 percent consols, which are replaced by 4 percent bonds in 1884. The Chinese series is based upon the yield ofan 8 percent bond issued in 1876 , replaced by a 7 percent bond issued in 1884, and later replaced by a 5 percent gold loan beginning in 1896. The Egyptian 4 percent bonds were issued in 1876 with a maturity of 65 years. For Japan, we use a 9 percent bond issued in 1870, then a 7 percent bond issued in 1873 and redeemed with the adoption of the Gold Standard in 1897; after 1897 we use a 5 percent bond with a maturity of 53 years. Portuguese bonds are 3 percent consols. Queensland issues have a redemption date in 1913. Russian and Swedish bonds are consols throughout our sample period. As for Turkey, the calculation of yields during the 1875-1883 period when Turkey suspended interest payments is based on the assumptions that coupon interest payments are made, reflecting the cost of capital to the Turkish government, rather than the interest earned by investors.

The data on British consols are drawn from the NBER MacroHistory Database; they are available from the Internet at http://www.nber.org/dalabases/macrohistory/contents/chapter13.html, series code $m l 3041$.

The data on U.S. long-term interest rates are drawn from the U.S. Treasury's web site, series code $t c m 30 y$.

The data on exports in local currency for 1870-1913 are drawn from Mitchell's International Historical Statistics (1750-1993), volumes for Europe (4th edition), the Americas (4th edition), and Africa, Asia, and Oceania (3" edition).

The data on exchange rates in 1870-1913 are drawn from Schneider et al. (1991). They are also available from www.globalfindata.com.

The data on exports in U.S. dollars in 1966-1998 are drawn from International Financial Statistics, International Monetary Fund.

The data on the composition of emerging markets' debt by type of instrument are drawn from the 1999 Annual Debt Trading Volume Survey-Supplemental Analysis, Emerging Markets Traders Association EMTA, New Yark, NY, and complemented using EMTA data available from the Internet at http://www.securities.com/.

The asymptotic standard errors of the percentage of total variation accounted for by the first principal component are computed using the routine PCA in the Stata Technical Bulletin, downloadable from http://www.stata.com/stb/stb37/. 


\section{EMERGING MARKETS' BOND ISSUES IN LONDON, 1870-1913}

Suzuki (1994) estimates that net foreign government loan issues on the London bond market between 1870 and 1913 amounted to $£ 2.1-3.9$ billion. Information on bond issues by countries included in our historical sample is presented in the Table 15.

Table 15. Net Proceeds from Bond Issues on the London Market, 1870-1913

\begin{tabular}{ccc}
\hline Country & $\begin{array}{c}\text { In Thousands of } \\
\text { British Pounds }\end{array}$ & Total Proceeds I/ \\
\hline Argentina & 87,379 & 4.0 \\
Brazil & 119,065 & 5.5 \\
China & 41,774 & 2.0 \\
Egypt & 123,745 & 5.7 \\
Japan & 82,103 & 3.8 \\
Portugal & 22,517 & 1.0 \\
Queensland & $\mathbf{n . a .}$ & $\mathbf{n . a .}$ \\
Russia & 248,388 & 11.5 \\
Sweden & 15,503 & 1.0 \\
Turkey & 120,697 & 5.5 \\
\hline
\end{tabular}

Source: Suzuki (I 994).

1/ In percent of total net issues on the London market by all countries. 


\section{ROBUSTNESS TESTS-PRINCIPAL COMPONENTS ANALYSIS}

This Appendix reports robustness tests of the results of the principal components analysis. It shows that when any one or two countries at a time are dropped from the various samples considered, the results remain broadly the same.

When analyzing emerging market spreads in historical times (1877-1913), and omitting Turkey from the sample, the percentage of variation in the nine series accounted for by the first principal component is 52.0 percent-the standard error of that percentage is 2.0 percentage points (Table 16). When one country at a time is dropped from the sample, the percentage of variation accounted for by the first principal component in the remaining seven series ranges from 48.8 percent (when Argentina is dropped) to 57.8 percent (when Portugal is dropped). When two countries at a time are dropped from the sample, the percentage of variation accounted for by the first principal component in the remaining six series ranges from 45.1 percent (when Argentina and Sweden are dropped) to 65.2 percent (when Brazil and Portugal are dropped).

Table 16 shows that the percentage of variation accounted for by the first principal component remains broadly the same when dropping any one or two countries from each of the samples considered in the main text: the historical sample including the full crisis episode in Turkey; the main modern sample of the eight emerging markets (Argentina, Brazil, Bulgaria, Mexico, Nigeria, the Philippines, Poland, and Venezuela) for which the EMBI spread data are available since November 1994, using monthly data; the main modern sample, using daily data; and the larger sample of fourteen countries (Argentina, Brazil, Bulgaria, Ecuador, Korea, Mexico, Morocco, Nigeria, Panama, Peru, the Philippines, Poland, Russia, and Venezuela) for which EMBI+ spread series are available since April 30, 1998, using daily data). 
Table 16. Share of Total Variation Accounted for by the First Principal Component

(In percent)

\begin{tabular}{|c|c|c|c|c|c|}
\hline$\underline{\text { Sample }}$ & Full Sample & $\begin{array}{c}\text { Minimum Dropping } \\
\text { One Country }\end{array}$ & $\begin{array}{c}\text { Maximum } \\
\text { Dropping One Country }\end{array}$ & $\begin{array}{c}\text { Minimum } \\
\text { dropping Two Countries }\end{array}$ & $\begin{array}{c}\text { Maximum } \\
\text { Dropping Two Countries }\end{array}$ \\
\hline $\begin{array}{l}\text { 1877-1914 Monthly. } 9 \text { countries. } \\
\text { Excluding Turkey }\end{array}$ & $\begin{array}{l}52.0 \\
(2.0)\end{array}$ & $\begin{array}{l}48.8 \text { dropping } \\
\text { Argentina }\end{array}$ & 57.8 dropping Portugal & $\begin{array}{l}45.1 \text { dropping Argentina } \\
\text { and Sweden }\end{array}$ & $\begin{array}{l}65.2 \text { dropping Brazil and } \\
\text { Portugal }\end{array}$ \\
\hline $\begin{array}{l}\text { 1875-1914 Monthly, } 8 \text { countries, } \\
\text { Including Turkey }\end{array}$ & $\begin{array}{l}45.7 \\
(1.9)\end{array}$ & $\begin{array}{l}42.0 \text { dropping } \\
\text { Sweden }\end{array}$ & 51.9 dropping Portugal & $\begin{array}{l}43.2 \text { dropping Japan and } \\
\text { Sweden }\end{array}$ & $\begin{array}{l}60.0 \text { dropping Brazil and } \\
\text { Portugal }\end{array}$ \\
\hline $\begin{array}{l}1994-2000 \text { EMBI Monthly, } \\
8 \text { countries }\end{array}$ & $\begin{array}{l}80.0 \\
(3.1)\end{array}$ & $\begin{array}{l}78.3 \text { dropping } \\
\text { Argentina }\end{array}$ & 83.7 dropping Bulgaria & $\begin{array}{l}76.9 \text { dropping Argentina } \\
\text { and Venezuela }\end{array}$ & $\begin{array}{l}85.6 \text { dropping Brazil and } \\
\text { Bulgaria }\end{array}$ \\
\hline $\begin{array}{l}1994-2000 \text { EMBI Daily, } \\
8 \text { countries }\end{array}$ & $\begin{array}{l}81.3 \\
(0.7)\end{array}$ & $\begin{array}{l}79.7 \text { dropping } \\
\text { Argentina }\end{array}$ & 84.7 dropping Bulgaria & $\begin{array}{l}78.3 \text { dropping Argentina } \\
\text { and Mexico }\end{array}$ & $\begin{array}{l}86.6 \text { dropping Brazil and } \\
\text { Bulgaria }\end{array}$ \\
\hline $\begin{array}{l}1998-2000 \text { EMBI+ Daily, } \\
14 \text { countries }\end{array}$ & $\begin{array}{r}72.2 \\
(1.8) \\
\end{array}$ & $\begin{array}{l}69.9 \text { dropping the } \\
\text { Phili22ines }\end{array}$ & 78.0 dropping Korea & $\begin{array}{l}68.2 \text { dropping Peru and } \\
\text { the Philippines }\end{array}$ & $\begin{array}{l}83.4 \text { dropping Ecuador and } \\
\text { Korea }\end{array}$ \\
\hline
\end{tabular}

The numbers in parentheses are standard errors of the percentage of total variation accounted for by the first principal component.

The first principal component is computed using the correlation matrix (i.e., the spreads divided by their standard deviation).

Data sources: The Economist, and J.P. Morgan. 


\section{REFERENCES}

Aziz, Caramazza, and Salgado (2000), "Currency Crises-In Search of Common Elements," IMF Working Paper No. 00/67.

Bardo, Michael and Barry Eichengreen (1999), "Is Our Current International Economic Environment Unusually Crisis Prone?" in Capital Flows and the International Financial System, Reserve Bank of Australia. Available via the Internet at http://emlab.berkeley.edu/users/eichengr/research.htm.

Bardo, Michael and Barry Eichengreen (2000), "Is the Crisis Problem Becoming More Severe?" presented at the Riksbank Conference on Asset Markets and Monetary Policy, June.

Borda, Michael, Barry Eichengreen and Jongwoo Kim (1998), "Was There Really an Earlier Period oflnternational Financial Integration Comparable to Today?" NBER Working Paper No. 6738. Available via the Internet at http://papers.nber.org/papers/w6738.

Borda, Michael and Hugh Rockoff (1998), "The Gold Standard as a Good Housekeeping Seal of Approval",Journal of Economic History, Vol. 56, No. 2, pp. 389--428.

Caprio, Gerard and Daniela Klingebiel (1999), "Episodes of Systemic and Borderline Financial Crises," manuscript, The World Bank.

Cochrane, John H. (1991), "Comment on Campbell and Perron," in Olivier Blanchard and Stanley Fischer, NEER Macroeconomics Annual, pp. 201-210.

Eichengreen, Barry (1997), "The Baring Crisis in a Mexican Mirror," in Lustig, Nora (ed.), Essays in Honor of Albert Fish/ow, forthcoming, Ann Arbor: University of Michigan Press.

Estevadeordal, Antoni (1997), "Measuring Protection in the Early Twentieth Century," European Review of Economic History, Vol. 1, No. 1, pp. 89-126.

Fishlow, Albert (1985), "Lessons from the Past: Capital Markets During the $19^{\text {th }}$ Century and the Interwar Period," International Organization, Vol. 39, No. 3, 383--439.

Flandreau, Marc (1998), "Caveat Emptor: Coping with Sovereign Risk Without the Multilaterals," CEPR Discussion Paper 2004.

International Monetary Fund (1997), International Capital Markets Report, Washington DC. Available via the Internet at http://www.imf.org/external/pubs/ft/icm/97icm/icmcon.htm.

Kamin, Steven B., and Karsten van Kleist (1999), "The Evolution and Determinants of Emerging Market Credit Spreads in the 1990s," BIS Working Paper No. 68, Bank for 
International Settlements, Basie, Switzerland. Available via the Internet at http://www.bis.org/publ/index.htm.

Lindert, Peter H. and Peter J. Morton (1989), "How Sovereign Debt Has Worked," in Developing Country Debt and Economic Performance, edited by Jeffrey Sachs and Susan Collins, The University of Chicago Press, pp. 39-106.

Mitchell, Brian R., 1998, International Historical Statistics, Stockton Press, New York.

Nellis, Joseph G. (I 982), "A Principal Components Analysis oflnternational Financial Integration Under Fixed and Floating Exchange Rate Regimes," Applied Economics, 14, pp. 339-354.

Obstfeld, Maurice, and Alan M. Taylor (1998), "The Great Depression as a Watershed: International Capital Mobility over the Long Run," in The Defining Moment: The Great Depression and the American Economy in the Twentieth Century, edited by Michael D. Bardo, Claudia Goldin, and Eugene N. White, University of Chicago Press, Chicago, IL, pp. 353-402.

O'Rourke, Kevin, and Jeffrey G. Williamson (1998), Globalization and History: The Evolution of a Nineteenth Century Atlantic Economy, Cambridge, MA: MIT Press.

Perron, Pierre (1989), "The Great Crash, the Oil Price Shock, and the Unit Root Hypothesis," Econometrica, Vol. 57, pp. 1361-1401.

Sachs, Jeffrey, and Andrew Warner (1995), "Economic Reform and the Process of Global Integration," Brookings Papers on Economic Activity, Vol. 1, 1-118.

Sclmeider, Jurgen, Oskar Schwarzer, and Friedrich Zellfelder, eds., 1991, Wahrungen der Welt, Stuttgart, Germany: F. Steiner.

Sussman, Nathan, and Yafeh, Yishay (1999), "Contagion and Capital Market Integration in Asia: Historical and Contemporary Evidence," Seoul Journal of Economics, Vol. 12, No. 4 (conference issue), 391-417.

Sussman, Nathan, and Yafeh, Yishay (2000), "Institutions, Reforms, and Country Risk: Lessons from Japanese Government Debt in the Meiji Period," Journal of Economic History, Vol. 60, No. 2, pp. 442-467.

Suzuki, Toshia (1994), Japanese Government Loans on the London Capital Market, 18701913 (Athlone Press, London). 